\title{
Plain Meaning and Hard Cases
}

The Language of Judges. By Lawrence M. Solan. ${ }^{*}$ Chicago: University of Chicago Press, 1993. Pp. xii, 218. $\$ 45.00$ (cloth), \$16.95 (paper).

\author{
Clark D. Cunningham, ${ }^{\dagger}$ Judith N. Levi, ${ }^{\dagger \dagger}$ Georgia M. Green, ${ }^{\dagger+t}$ and \\ Jeffrey P. Kaplan ${ }^{\text {ttt }}$
}

If the language of a statute is plain, how can interpreting that statute create a hard case? And if a case is hard, how can recourse to the statutory language help resolve the case? This essay will explore the apparent paradoxes raised by these questions. In his recent book, The Language of Judges, Lawrence Solan, a lawyer first trained as a linguist, uses linguistics to critique a variety of opinions in which he believes the Supreme Court has erroneously claimed that its decision was based on the plain meaning of a statute. After examining Solan's conclusions, this essay will use his book to show how linguists can provide very useful information as to whether a text is ambiguous. In doing so, we hope to go beyond Solan's intentionally narrow undertaking-using linguistics to critique judicial decisions after the fact for treating ambiguous texts as if they were plain-to experiment with ways that analysis of ambiguous texts by linguists could actually assist judges in identifying and choosing among possible interpretations in a principled and objective way that remains grounded in the textual language.

It is probably safe to assume that most statutory interpretation cases before the Supreme Court present hard problems of textual analysis, especially where there has been a split among the circuit courts of appeal. When this essay was commissioned in July 1993, Cunningham ${ }^{1}$ reviewed all of the cases in which

* Partner, Orans, Elsen and Lupert.

$\dagger$ Professor of Law, Washington University (St. Louis).

ti Associate Professor, Department of Linguistics, Northwestern University.

itt Professor, Department of Linguistics, University of Illinois (Urbana-Champaign).

t+t† Associate Professor, Department of Linguistics, San Diego State University. The authors appreciate the helpful comments and advice received from Susan Appleton, Stuart Banner, Kathleen F. Brickey, Daniel A. Farber, Richard Lazanus, Ronald M. Levin, Lynn LoPucki, William D. Popkin, Lee Robins, Frederick Schauer, Dana Underwood, and participants in faculty workshop presentations of early versions of this essay at the University of Wisconsin Law School and Washington University Law School. The authors are also indebted to Clayton Boyer and Rebecca Ison for assistance with computer technology; to Hyla Bondareff and Peggy McDermott for reference librarian services; and to Claire E. Weiss, Robert Gans, Karen Dill, and Polina Shklyanoy for research assistance.

1. Unilike the other authors, Cunningham is not a professionally trained linguist. He has, however, written about various applications of linguistics to law. See The Lawyer as Translator, Representation as 
the Supreme Court had granted certiorari in the ten weeks immediately preceding its summer recess, with the thought that these cases would be deferred long enough for one or more linguists to analyze the disputed texts prior to the oral arguments. He selected three cases in which the outcome might turn on the meaning of a statutory provision in ordinary language. ${ }^{2}$ Cunningham then contacted Levi ${ }^{3}$ to help him identify and recruit academic linguists willing to analyze the statutory provisions at issue in these cases using the methods of modern linguistics. ${ }^{4}$ He prepared one-page summaries of each of the cases and sent them to the linguists identified by Levi. Two, Kaplan ${ }^{5}$ and Green, ${ }^{6}$ agreed to take on major responsibility for the project, along with Levi.

In each case, our analysis demonstrates that the disputed text is ambiguous and reveals that the lower courts' efforts to resolve the ambiguity are seriously flawed as a matter of ordinary language interpretation. ${ }^{7}$ The linguists' analysis

Text: Towards an Ethnography of Legal Discourse, 77 CORNELL L. REv. 1298 (1992); A Linguistic Analysis of the Meanings of 'Search' in the Fourth Amendment: A Search for Common Sense, 73 IowA L. REv. 541 (1988) [hereinafter Cunningham, A Linguistic Analysis]; A Tale of Two Clients: Thinking About Law as Language, 87 MiCH. L. REv. 2459 (1989).

2. Out of the 26 cases for which certiorari had been granted between April 26, 1993 and July 1, 1993 , three cases were selected: United States v. Staples, 971 F.2d 608 (10th Cir. 1992), cert. granted, 113 S. Ct. 2412 (1993), discussed infra pp. 1573-77; United States v. Granderson, 969 F.2d 980 (11th Cir. 1992), cert. granted, 113 S. Ct. 3033 (1993), discussed infra pp. 1577-81, 1582; and National Organization for Women, Inc. v. Scheidler, 968 F.2d 612 (7th Cir. 1992), cert. granted, 113 S. Ct. 2958 (1993), rev'd, 114 S. Ct. 798 (1994), discussed infra pp. 1588-1613. We also selected a fourth case, United States v. Knox, 977 F.2d 815 (3d Cir. 1992), cert. granted, 113 S. Ct. 2926, vacated and remanded, 114 S. Ct. 375 (1993), and conducted considerable empirical research before the Court remanded the case in November in response to a change in position by the government regarding the "plain meaning" of the statutory provision at issue (prohibiting possession of videotapes containing "lascivious exhibition of the genitals or pubic area" of a minor, 18 U.S.C. $\$ 2256(2)(E)(1988)$ ). In light of this development, we decided not to include our analysis of Knox in this essay but may discuss the case in a later article. The Justices received galley proofs of this essay on November 22, 1993, one week before the Court heard oral argument in the Staples case. (The NOW case was argued on December 8, 1993 and Granderson on January 10, 1994.) Copies were also sent to counsel of record for the parties in Staples, NOW, and Granderson and to the United States as amicus curiae in the NOW case. A brief discussion of the Court's decision in the NOW case, which was issued on January 24, 1994 as this essay was going to press, appears at the end of Part VII, supra note 197.

3. Levi, a theoretical linguist and former chair of the Northwestern University Linguistics Department, has been writing for more than a decade about social science research on language and law, as well as about applications of linguistics to legal cases. She has participated as a consultant or expert witness in more than 20 legal cases since 1978. During that period, she has also served as a sort of clearinghouse for information relating to both these domains. Her publications include LANGUAGE AND LAW: A BibliographIC GuIde to SOClal SCIENCE RESEARCH IN THE U.S.A. (American Bar Ass'n 1994) and Language in the Judicial Process (Judith N. Levi \& Anne G. Walker eds., 1990).

4. These methods are briefly described infra pp. I568-69.

5. Kaplan is the author of ENGLISH GRAMMAR: PRINCIPLES AND FACTS (1989). Much of his research in recent years has focused on the language of law and on the application of linguistics to legal issues. See, e.g., Jeffrey P. Kaplan, Syntax in the Interpretation of Legal Language: The Vested Versus Contingent Distinction in Property Law, 68 AM. SPEECH 58 (1993).

6. Green has published widely on matters of syntactic theory and on semantic and pragmatic interpretation in natural language understanding. She is the author of PRAGMATICS AND NATURAL LANGUAGE UNDERSTANDING (1989) [hereinafter GREen, PRAgmatics], and the coeditor of LiNGUistic COMPLEXITY AND TEXT COMPREHENSION (Georgia Green \& Alice Davison eds., 1988), and LINGUISTICS AND COMPUTATION (Georgia Green et al. eds., forthcoming 1994).

7. Throughout this essay we use the terms ambiguous and ambiguity in the broad sense found frequently in legal usage, where the terms describe language about whose interpretation reasonable people 
of the textual ambiguity, however, provides significant guidance toward identifying the sources of the ambiguity. This analysis narrows the field of possible interpretations in ways that are both linguistically and intuitively sensible, making the court's decision more coherent and understandable to the various audiences the court must address. Although the discussion draws upon theoretical concepts that may be unfamiliar to lawyers and judges, and in one case employs empirical research, we believe that our conclusions would make sense to judges because the analysis articulates linguistic distinctions that all members of the relevant speech community ${ }^{8}$ can recognize once they are brought to conscious attention. Indeed, judges are already accustomed to the use of dictionaries to serve exactly such purposes: to remind them of what they already know, to inform them of what they may not know (such as the meaning of words not encountered before or technical meanings of certain words in specialized fields such as medicine or science), and to help them make distinctions. ${ }^{9}$ Unfortunately, compared to analysis of a particular textual problem by a trained linguist, dictionaries are a crude and frequently unreliable aid to word meaning and usage. In fact, for one of the three cases, ${ }^{10}$ the leading dictionaries have definitions that differ exactly as the parties differ over the meaning of the statutory term, ${ }^{11}$ and thus provide no objective way of resolving that dispute over ordinary language meaning.

In the lively debate about statutory interpretation currently occurring among both legal scholars and judges, the phrase "plain meaning" itself presents interpretive difficulties. "Plain meaning" is sometimes invoked to

may differ. In contrast, linguists use these terms to characterize only one category of such language: language that has two (or more) specific and specifiable competing meanings. Ambiguity in this narrower sense can be further distinguished between the ambiguity of a single word (lexical ambiguity)-for example, pen as either writing instrument or animal enclosure, or ambiguity of sentence structure (structural ambiguity)-for example, The chicken is ready to eat as either The chicken is ready for someone to eat or The chicken is ready to eat something. When we wish in this essay to narrow the use of ambiguity to what linguists treat as ambiguity, we will use the terms lexical ambiguity and structural ambiguity.

8. A speech community has been defined as "a community sharing knowledge of rules for the conduct and interpretation of speech." DELL H. HYMES, FOUNDATIONS IN SOCIOLINGUISTICS 51 (1974). There are any number of overlapping speech communities that share English as their primary or sole language. The assumed relevant speech community for our analyses is the contemporaneous set of literate and welleducated native speakers of English in the United States, except where technical legal meaning is involved, in which case the community is the smaller professional subset of lawyers and judges. Congress enacted the statutory provisions at issue in the three cases within the past 25 years, making unlikely the possibility of significant difference in linguistic conventions between the community at the time of enactment and today. Even if such differences exist, the community at the time of the judicial decision is still the relevant community for at least some purposes when that decision relies on ordinary language.

9. See Nix v. Hedden, 149 U.S. 304, 307 (1893) ("[T] he court is bound to take judicial notice, as it does in regards to all words in our own tongue; and upon such a question dictionaries are admitted, not as evidence, but only as aids to the memory and understanding of the court.") (citations omitted).

10. National Org. of Women, Inc. v. Scheidler, 968 F.2d 612 (7th Cir. 1992), cert. granted, 113 S. Ct. 2958 (1993), rev'd, 114 S. Ct. 798 (1994).

11. The dispute is over the meaning of enterprise as a necessary element for a claim under the Racketeer Influenced and Corrupt Organization Act, 18 U.S.C. \$\$ 1961-1968 (1988). See Scheidler, 968 F.2d at 625-30.

12. For a representative sample of the extensive scholarship recently produced on this subject, see T. Alexander Aleinikoff, Updating Statutory Interpretation, 87 MICH. L. REV. 20 (1988); William N. Eskridge, 
indicate that the meaning of a provision is "clear" and "unambiguous." The following statement from a recent Supreme Court decision is typical:

In a statutory construction case, the beginning point must be the language of the statute, and when a statute speaks with clarity to an issue judicial inquiry into the statute's meaning, in all but the most extraordinary circumstance, is finished. ... The controlling principle in this case is the basic and unexceptional rule that courts must give effect to the clear meaning of statutes as written. ${ }^{13}$

When the "plain meaning" rule is given this interpretation, one would not expect the rule to be invoked very often in Supreme Court opinions, unless the issue were whether an extraordinary circumstance required inquiry beyond the plain meaning. For if the statutory provision was clear and unambiguous, one would not expect to find the kind of disagreement among lower courts that warrants Supreme Court review. But as Frederick Schauer has persuasively shown, the "plain meaning" cases that have occupied much of the Supreme Court's attention in recent years did not necessarily become hard because of the "exceptional situation" caveat to the plain meaning rule:

[In many of the statutory construction cases of the 1989 term] where the plain meaning is subject to dispute, there still seems to be agreement that it remains the appropriate focus of legal argument. . . [T] he grounds for the debate, even when there was a debate, were not whether plain meaning would dominate, but just what the plain meaning was. ${ }^{14}$

One of Solan's most powerful critical moves is to analyze the seemingly embarrassing paradox in Supreme Court cases where all nine Justices agreed that the meaning of a provision was "plain," but split five to four over what that provision meant. ${ }^{15}$

At other times, "plain meaning" seems to take on a different sense, one that perhaps explains how hard cases can focus on plain meaning. In the following recent dissent, Justice Scalia points to the rule of "plain meaning" as being about ordinary rather than unambiguous meaning.

The New Textualism, 37 UCLA L. REV. 621 (1990); William D. Popkin, An "Internal" Critique of Justice Scalia's Theory of Statutory Interpretation, 76 MiNN. L. Rev. 1133 (1992); Frederick Schauer, Statutory Construction and the Coordinating Function of Plain Meaning, 1990 SUP. CT. REV. 231; David L. Shapiro, Continuity and Change in Statutory Interpretation, 67 N.Y.U. L. REV. 921 (1992); Symposium, $A$ Reevaluation of the Canons of Statutory Interpretation, 45 VAND. L. REV. 529 (1992).

13. Estate of Cowart v. Nicklos Drilling Co., 112 S. Ct. 2589, 2594 (1992) (Kennedy, J.); see also Demarest v. Manspeaker, 498 U.S. 184, 190 (1991) (Rehnquist, C.J.) (unanimous decision) ("When we find the terms of a statute unambiguous, judicial inquiry is complete except in rare and exceptional circumstances.").

14. Schauer, supra note 12 , at $242-43$.

15. See infra pp. 1571,1582 , and 1585 . 
I thought we had adopted a regular method for interpreting the meaning of language in a statute: first, find the ordinary meaning of the language in its textual context; and second, using established canons of construction, ask whether there is any clear indication that some permissible meaning other than the ordinary one applies. If not-and especially if a good reason for the ordinary meaning appears plain-we apply that ordinary meaning. ${ }^{16}$

For Justice Scalia, and quite possibly for a number of his fellow Justices, invocation of "plain meaning" represents a decision to give greater weight to the text as compared to legislative history and policy considerations. William Eskridge has termed this approach the "new textualism"17 and has identified several policy justifications advanced for this greater attention to text: (1) the ordinary meaning of the text is a more reliable guide than legislative history to the intent of all the actors in the federal legislative process (including the President who refrains from exercising veto power); (2) the ordinary meaning is more accessible and comprehensible to officials and citizenry affected by the legislation; and (3) ordinary meaning can constrain judicial discretion more effectively than can recourse to legislative history. ${ }^{18}$

Much of the scholarly attention devoted to new textualism has attacked the soundness of one or more of these policy justifications. This essay does not address these difficult jurisprudential issues. Rather, it explores what assistance linguistics can give to a judge to the extent she chooses for whatever reason to use the ordinary language meaning of a text to guide her decisionmaking. Linguistics has something to offer for both versions of the "plain meaning rule." For the "plain means unambiguous" side, linguists can determine empirically whether a phrase is ambiguous as a matter of ordinary language. Even more importantly, for Justice Scalia's "plain means ordinary meaning" strand, linguists can help a judge explore and articulate the judge's intuitive but usually unconscious understanding of ordinary meaning. "Ordinary" meaning can be ambiguous at times. Where an ordinary language reading of a text can produce two or more plausible interpretations, judges face a dilemma. How can two judges discuss, much less resolve, differing views about what a provision "plainly" means? According to Eskridge, the "new

16. Chisom v. Roemer, 111 S. Ct. 2354, 2369 (1991). Chief Justice Rehnquist and Justice Kennedy joined in Justice Scalia's dissenting opinion. Id; see also Smith v. United States, 113 S. Ct. 2050, 2054 (1993) (O'Connor, J.) ("When a word is not defined by statute, we normally construe it in accord with its ordinary or natural meaning."); Russello v. United States, 464 U.S. 16, 21 (1983) (Blackmun, J.) (stating that when a term is not specifically defined in statute, court starts "with the assumption that the legislative purpose is expressed by the ordinary meaning of the words used") (quoting Richards v. United States, 369 U.S. 1,9 (1962)).

17. Eskridge, supra note 12 , at 623 .

18. Id.; see also Green v. Bock Laundry Mach. Co., 490 U.S. 504, 528 (1989) (Scalia, J., concurring). A fourth argument for reliance on ordinary meaning is that it may produce more internally coherent case law than decisionmaking that assigns new technical meaning to key terms that have well established, albeit complex, meanings in ordinary usage. See Cunningham, A Linguistic Analysis, supra note 1. 
textualism" would replace reference to legislative history with "dictionaries and grammar books ... and the common sense God gave us."19 As this essay hopes to show, judges rely on dictionaries at their peril to resolve questions of meaning, but the methods of linguistic science can significantly inform their innate "common sense" about their own language, thus providing some objective and principled ways to deliberate over hard cases of interpretation. ${ }^{20}$

In Part I we summarize Solan's overview of the discipline of linguistics as it might relate to the study of law and add some observations of our own. Parts II through V illustrate how linguistics can explicate hard cases arising from uncertain relations among words in a sentence or between words and their larger context. All the examples are drawn from Supreme Court cases: Parts II and V are based on Solan's analysis of past Supreme Court decisions, while in Parts III and IV we propose analyses of two cases pending before the Supreme Court in the 1993-94 term. Parts VI and VII address the problem of interpreting words referring to conceptual categories whose boundaries seem to be uncertain or "fuzzy." All the examples relate to statutory terms in the Racketeer Influenced and Corrupt Organizations Act (RICO): Part VI to Solan's analysis of past Supreme Court decisions interpreting RICO, and Part VII to our extended analysis of another RICO case pending before the Supreme Court. Part VII is, significantly, the longest section of this essay because, unlike the analyses in Solan's book, it illustrates the use of empirical research methods which expand the database for analysis beyond the linguist's introspection and intuitive understanding of his own language. ${ }^{21}$

\section{LINGUISTICS AND THE LAW}

One of many refreshing things about The Language of Judges is that, although the book is published by a leading university press, its author is not an academic but a practicing lawyer. Lawrence Solan received a Ph.D. in linguistics from the University of Massachusetts, but decided to go to Harvard Law School rather than become a college professor. Following a clerkship with a New Jersey Supreme Court justice, he joined a New York City law firm, where he is now a partner.

Given Solan's background as a professionally trained linguist, one might expect his book to focus on ways that linguistics could contribute to the work of judges, especially to help them decide hard cases. His project, however, has a different focus: "The issue that [Ronald] Dworkin raises is how judges

19. Eskridge, supra note 12, at 669 .

20. This essay does not contend, though, that linguistics will make hard cases easy or produce the "right answer" to cases.

21. Additional information about the empirical methods and results discussed in Part VII is found in the appendices to this essay and is on file with the authors. 
decide hard cases. The issue that I raise is a different one: how judges attempt to mask the fact that a case is hard in the first place."22

Solan uses linguistics to demonstrate how judges avoid acknowledging demonstrable ambiguity. He urges judges faced with hard cases to acknowledge both the indeterminacy of the text and their reliance on nontextual sources for their decision. Solan's book does more, however, than enlist linguistics in the service of a familiar realist critique of judging. First, it explains the discipline of linguistics with clarity, both in an excellent overview that appears in the first chapter and throughout the remainder of the book. Second, it progressively educates the reader as to the wide variety of ways linguistics can illuminate legal texts, as Solan carefully walks through each example of how the judges got it wrong. Third, the book goes beyond its professed narrow goal of critiquing existing judicial practices to show how the explication of the shared competence of all speakers can provide a basis for improving the quality of judicial discourse.

Solan begins the first chapter of his book by summarizing Justice Cardozo's famous discussions of the paradox of law:

[The law must] be both sufficiently flexible to accommodate new cases as they arise and sufficiently rigid to maintain its predictive power. If the law is not flexible enough, then it is doomed to irrelevance and to becoming the source of injustice. If the law is too flexible, then it becomes so unstable that it fails to define with any reliability people's rights and obligations ....23

He then quotes Cardozo directly:

No doubt the ideal system, if it were attainable, would be a code at once so flexible and so minute, as to supply in advance for every conceivable situation the just and fitting rule. But life is too complex to bring the attainment of this ideal within the compass of human powers. $^{24}$

Solan asserts that Cardozo's wistful fantasy of the "ideal code" describes the reality of language. This is true in the sense that our language is flexible enough to enable us to use it in describing - or imagining - circumstances that are quite novel to us. Moreover, just as we encounter new experiences all the time and use our existing language to talk about them, so we routinely hear sentences we have never heard before and yet interpret them without pause and usually without conscious effort. That we accomplish these cognitive tasks

22. Lawrence M. Solan, The Language of Judges 208 n.10 (1993).

23. Id. at 12 .

24. Id. at 13 (quoting Benjamin Cardozo, The Nature of the Judicial Process 143 (1921)). 
with relative ease and swiftness does not mean, however, that our interpretations of what we hear and read are invariably correct.

Although we are reluctant to take literally Solan's description of language as an "ideal code," it is true that linguistics has made considerable progress in finding and analyzing predictable order in the seemingly infinite variety of speech. The same exploratory methods that have enabled linguists to make significant scientific progress in recent decades can also assist judges in finding and analyzing predictable order in the complex textual issues which so frequently make cases hard.

What is the nature of this discipline, which is at the same time so appropriate for use by judges and yet still so unfamiliar to most? Simply stated, linguistics is the scientific study of human language. Linguistics addresses such questions as: What do you know when you know a language? What do you learn when you learn a language? What do all languages have in common? How do languages differ? The analyses in this essay draw primarily upon three areas in the field of linguistics: syntax-the principles governing the structure of sentences; semantics-the principles governing representational connections between language and the world, and governing meaning connections among words and sentences; and pragmatics-principles governing how interpretation can be affected by context. ${ }^{25}$

Linguists test their hypotheses according to the familiar principles of the scientific method: they deduce contrasting predictions of opposed hypotheses and measure those predictions against observable aspects of reality. Because the hypotheses and their predictions do not typically involve observable reality, and because the reality that linguists try to describe is the set of abstract and complex rules underlying language use, linguists have to make inferences from people's linguistic behavior under both natural and controlled conditions. They analyze the contexts in which people naturally use words and constructions, in order to infer the senses of those words or the discourse function of those constructions. Linguists also investigate the judgments made by native speakers about whether a given sentence could mean something particular or whether it would be natural to use it to mean anything at all. While intuition guides the critical first steps of linguists, their hypotheses are always subject to empirical testing. ${ }^{26}$ Several types of empirical tests will be demonstrated later in this essay in the discussion of one of the pending Supreme Court cases.

25. Other areas of linguistics are phonetics-the study of the mechanics of speech sound production and the classification of speech sounds; phonology - the rules governing the sound system of a language; morphology - the rules governing the internal structure of words; and discourse analysis-various approaches to the structure of discourses (stretches of speech or writing longer than a sentence). Each of these areas of linguistics can be applied to one or more languages, or to language generally as in the study of linguistic universals.

26. The commitment to test conclusions empirically is an important feature that identifies linguistics as a science and distinguishes it from philosophical inquiry, which is not similarly constrained. 
The routine work of linguists is to articulate the conventions that distinguish one language from another. Ordinary speakers of our language are generally unaware of these conventions, and are unprepared to articulate them. English speakers, for example, might have difficulty explaining why they say the tall one and someone tall, but not the one tall or tall someone, despite the fact that it would never occur to them to speak any differently. Somewhat similarly, ordinary speakers are not aware of how many different kinds of linguistic conventions they are unconsciously relying on for every sentence they utter or interpret, from rules of pronunciation to rules of syntax, and from rules of contextual inference of facts to rules for recognizing and reflecting social parameters of a particular interaction. Just as we are largely unaware of the breadth of this system of unconscious linguistic competence, so we are largely unaware of the depth of specificity that can be incorporated into a single convention. ${ }^{27}$

In his book, Solan most frequently applies the linguist's ability to articulate linguistic conventions to the analysis of contested legal texts through the following steps. First, he identifies the portion or feature of the text that appears to be at issue in a reported case. He then provides one or more examples of non-legal discourse that seem to be ambiguous in the same way as the legal text. He shows that the ambiguity of these ordinary language examples can be explained through one or more well recognized linguistic principles, and often shows how the ambiguity disappears if the expression is reformulated. In these examples, Solan is able to use the reader's own competence as a speaker of English to validate the application of the linguistic principle. Finally, Solan extends the linguistic principle back to the legal text to explain how, as a matter of ordinary language, the text is ambiguous in nonobvious ways. Solan's approach operates most clearly and successfully in cases where the contested text is structurally ambiguous, and so we begin our discussion with such cases.

\section{StRUCTURAL Ambiguity}

Solan suggests that the first problem with the conventional version of the plain meaning rule, the version that equates plain with unambiguous, is that "it is not always easy to tell when a statute is ambiguous." ${ }^{28} \mathrm{He}$ then sets himself the task of discussing "from a linguistic point of view, what it means for language to be clear, and what causes language not to be clear."29 The

27. Trying to explain these conventions to non-native speakers of English is one situation that forces us to recognize such complexities. For example, imagine trying to explain which objects in the world can be called tall as opposed to high, or trying to tease out the subtle differences between: I lived there, I was living there, I have lived there, I did live there, and I have been living there.

28. SOLAN, supra note 22 , at 93.

29. Id. at 94 . 
two major causes of statutory ambiguity, according to his analysis, are "structural ambiguity" and problems of categorization. ${ }^{30}$ The latter topic, which Solan refers to as "concepts with fuzzy boundaries,"31 will be discussed in Parts VI and VII of this essay.

In cases of structural ambiguity, interpretive difficulties arise not from indeterminacy as to the meaning of individual words but from ambiguity as to the relationship of the words in a sentence structure. A famous example in linguistics is this phrase:

\section{(1) old men and women ${ }^{32}$}

This can refer to (a) men who are old and women who are old, or to (b) men who are old and women of any age. The difference depends on whether old forms a constituent with just men, or whether it forms a constituent with the coordinate phrase men and women.

Solan illustrates how structural ambiguity can create hard cases with two Supreme Court cases that were "hard" because of ambiguity as to the relationship between the adverb knowingly and the rest of a sentence in a statute.

In United States v. Yermian, ${ }^{33}$ the interpretive challenge arose under the federal False Statement Act, which provides in relevant part: "Whoever, in any matter within the jurisdiction of any department or agency of the United States knowingly and willfully ... makes any false ... statements ... shall be fined ... or imprisoned...."34 Yermian admitted to making a false statement on a security clearance form he submitted to his employer, a government defense contractor. His sole defense was that he did not know that the false statement was within the jurisdiction of a federal agency; he thought he was lying only to his private employer. ${ }^{35}$ The trial court rejected Yermian's interpretation that knowingly ${ }^{36}$ applied to within the jurisdiction as well as to makes any false statements. The court of appeals agreed with

30. Id. at $95-98$.

31. Id. at $96-99,104-08$.

32. We will follow the convention in linguistics of numbering all our examples sequentially, with closely related examples assigned the same number with differing letters, such as 4(a) and 4(b).

33. 468 U.S. 63 (1984).

34. The provision reads in full:

Whoever, in any matter within the jurisdiction of any department or agency of the United States knowingly and willfully falsifies, conceals or covers up by any trick, scheme, or device a material fact, or makes any false, fictitious or fraudulent statements or representations, or makes or uses any false writing or document knowing the same to contain any false, fictitious or fraudulent statement or entry, shall be fined not more than $\$ 10,000$ or imprisoned not more than five years, or both.

18 U.S.C. $\$ 1001$ (1988).

35. 468 U.S. at 66.

36. Throughout this essay, we follow the convention in linguistics of italicizing examples of words or phrases. 
Yermian, reversing his conviction. The Supreme Court split five to four, with the majority reinstating the conviction. The question of whether the statute was ambiguous had particular significance in this case because of the "rule of lenity," a canon of statutory construction stating that ambiguity in a criminal statute should be resolved in favor of the defendant. ${ }^{37}$ The majority's insistence that the statute was unambiguous is striking in that the four dissenting Justices and the three judges of the court of appeals had a different view of the scope of knowingly. Writing for the dissenters, then-Associate Justice Rehnquist stated:

[T] he Court's reasoning here amounts to little more than simply pointing to the ambiguous phrases and proclaiming them clear. In my view, it is quite impossible to tell which phrases the terms "knowingly and willfully" modify, and the magic wand of ipse dixit does nothing to resolve that ambiguity. ${ }^{38}$

By bringing to bear the linguistic significance of adverb positioning, Solan persuasively shows how even the threshold question of whether the statute was ambiguous presented a hard case. He reports that "[1]inguists have for many years recognized that the position of a prepositional phrase" affects interpretation of a sentence. ${ }^{39}$ Solan demonstrates that sentences with a prepositional phrase at the end, like sentence (2)(a) below, are more readily recognized as ambiguous than are sentences that are otherwise identical but have the prepositional phrase at the beginning, as in (2)(b):

(2)(a) Fred knowingly sold securities without a permit.

(2)(b) Without a permit, Fred knowingly sold securities. ${ }^{40}$

As Justice Rehnquist pointed out in his Yermian dissent, prior to its amendment in 1948, the statute did not prepose within the jurisdiction but instead read as follows: "[W]hoever shall knowingly and willfully... make ... any false ... statements ... in any matter within the jurisdiction of any department or agency of the United States ... shall be fined... or imprisoned." ${ }^{\prime 11}$ According to Solan's analysis, as a matter of ordinary

37. See Dowling v. United States, 473 U.S. 207, 213-16 (1985) ("Due respect for the prerogatives of Congress in defining federal crimes prompts restraint in this area, where we typically find a narrow interpretation' appropriate."). Two policy arguments for this rule are that those accused of crimes are entitled to clear notice of what is illegal, and that strict construction of criminal statutes preserves the role of the legislature in defining crimes. SoLAN, supra note 22, at 66-67. Solan uses Yermian and Liparota to claim that the Supreme Court has avoided application of the rule of lenity through linguistically unjustified denials that ambiguity exists. Id. at 67-76.

38. 468 U.S. at 77-78, quoted in SOLAN, supra note 22, at 70.

39. SOLAN, supra note 22 , at 71 .

40. Id. at $70-71$.

41. Act of June 18, 1934, ch. 587, 48 Stat. 996 (amended 1948), quoted in Yermian, 468 U.S. at 78 (Rehnquist, J., dissenting) and SOLAN, supra note 22, at 70. 
language, the earlier statute was more ambiguous than the version under which Yermian was charged. Yet all nine Justices apparently agreed that Congress did not intend to make any substantive changes in the state of mind requirement when it rewrote the statute in $1948 . .^{42}$ The majority maintained that the statute was unambiguous both before and after the amendment, while the dissenters found it just as ambiguous in either form.

The Court's decision a year after Yermian in Liparota v. United States ${ }^{43}$ supports Solan's analysis. A majority of six out of eight Justices, ${ }^{44}$ including two from the majority who had found the Yermian statute unambiguous, agreed that the following provision of the federal food stamp statute was ambiguous as to the scope of knowingly: "[W] hoever knowingly uses ... or possesses coupons or authorization cards in any manner not authorized by this chapter or the regulations issued pursuant to this chapter shall ... be fined ... or imprisoned . ..."45 Liparota argued that he had not knowingly used food stamps in a manner not authorized by law or regulation, but the trial court rejected that defense and instructed the jury that it need only find that Liparota knowingly possessed the food stamps. ${ }^{46}$

The majority of the Court in Liparota, finding the scope of knowingly to be ambiguous, ${ }^{47}$ applied the rule of lenity to interpret the statute in the defendant's favor ${ }^{48}$ and reverse the conviction. However, the majority did not respond to the dissenters' argument that the Court was bound by the Yermian precedent to find the statute unambiguous, since the grammatical position of knowingly in the pre-1948 version of the statute involved in Yermian was the same as in the food stamp provision. ${ }^{49}$

42. 468 U.S. at 72-74, 78-79; SOLAN, supra note 22 , at 70.

43. 471 U.S. 419 (1985).

44. Justice Powell did not participate in the decision. Id. at 434.

45. 7 U.S.C. $\$ 2024$ (b) (1988), quoted in SoLAN, supra note 22 , at 72 . The full provision reads: Subject to the provisions of paragraph (2) of this subsection, whoever knowingly uses, transfers, acquires, alters, or possesses coupons or authorization cards in any manner not authorized by this chapter or the regulations issued pursuant to this chapter shall, if such coupons or authorization cards are of a value of $\$ 100$ or more, be guilty of a felony and shall, upon the first conviction thereof, be fined not more than $\$ 10,000$ or imprisoned for not more than five years, or both, and, upon the second and any subsequent conviction thereof, shall be imprisoned for not less than six months nor more than five years and may also be fined not more than $\$ 10,000$ or, if such coupons or authorization cards are of a value of less than $\$ 100$, shall be guilty of a misdemeanor, and, upon the first conviction thereof, shall be fined not more than $\$ 1,000$ or imprisoned for not more than one year, or both, and upon the second and any subsequent conviction thereof, shall be imprisoned for not more than one year and may also be fined not more than $\$ 1,000$. In addition to such penalties, any person convicted of a felony or a misdemeanor violation under this subsection may be suspended by the court from participation in the food stamp program for an additional period of up to eighteen months consecutive to that period of suspension mandated by section $2015(\mathrm{~b})(1)$ of this title.

7 U.S.C. $\$ 2024(b)$.

46. 471 U.S. at 422 .

47. Id. at 424-25.

48. Id. at 427-29.

49. The Liparota majority distinguished Yermian on the grounds that the provision in that case was unambiguous and that either interpretation of it would include a mens rea requirement, but did not explain 


\section{The SCOPE of KNowingly: ThE STAPLes CASE}

The case of United States v. Staples, ${ }^{50}$ now pending before the Supreme Court, demonstrates how structural ambiguity and ambiguity as to specific word meaning ${ }^{51}$ can interact to create a hard case. The dispute once again turns on the scope of knowingly in a criminal statute.

Staples was convicted of violating the National Firearms Act because he failed to register a rifle that he owned. He was sentenced to five years probation and a $\$ 5000$ fine. The rifle in question was an AR-15 assault rifle ${ }^{52}$ that had been modified so that it could fire more than one shot with a single trigger pull, making it an automatic weapon, or in other words, a machinegun. Ordinary one-shot rifles do not have to be registered; machineguns do.

The indictment against Staples charged that he "knowingly received and possessed firearms,' described as follows: a. Inland Model M1 .30 caliber carbine, serial number 5222984; b. SGW Model XM1, .223 caliber rifle, serial number X2606 both of which had been modified so as to be machineguns, and neither of which were registered to" him..$^{53}$ The case nicely presents three different ways of interpreting knowingly possessed: (1) simple knowledge that the object was in his possession, (2) additional knowledge that the object was a dangerous weapon, or (3) further knowledge that the object was a specific type of weapon, namely a machinegun. As to the first weapon, the M1 carbine found in his bathroom closet during a search of his house by government agents, Staples denied even knowing that he possessed the object. ${ }^{54}$ The prosecution did not contest that the M1 was registered to the defendant's father, and the father testified that he was going to be away for a few days and left it in the closet without his son's knowledge. Thus the defendant did not knowingly possess the M1 even under the most limited of the three types of knowledge listed above. The jury acquitted Staples on the charge relating to the M1. ${ }^{55}$

In contrast, Staples admitted knowing that he possessed the SGW Model XM1 rifle (the AR-15), which the agents found in his home office during the same search. However, he denied knowing that the rifle "had been modified so as to be [a] machinegun." This denial made critical the choice between the second and third possible interpretations of knowingly possessed a firearm because firearm is a term of art under the National Firearms Act. In addition to machineguns, the term includes shotguns with barrel lengths under eighteen

how the analogous provision before it could be ambiguous in light of Yermian. Id. at 431-32.

50. 971 F.2d 608 (10th Cir. 1992), cert. granted, 113 S. Ct. 2412 (1993).

51. See supra note 7 for a discussion of the distinction between these two types of ambiguity.

52. The AR-15 is "the civilian version of the military's M-16 rifle," which is an automatic weapon.

Brief for the United States at 5, Staples (No. 92-1441).

53. Id. at 3 n.1.

54. Brief of Petitioner at 4 n.1, Staples (No. 92-1441).

55. Id. 
inches, rifles with barrel lengths under sixteen inches, and hand grenades, ${ }^{56}$ but not an unmodified AR-15 rifle. As a jury instruction, Staples proposed the third interpretation of knowingly possessed a firearm: " $[\mathrm{A}] \mathrm{n}$ essential element of the offense of possessing a machinegun, is that the possessor knew that the gun would fire fully automatically ...."57 The trial judge rejected this interpretation and instead instructed the jury using the second interpretation:

The Government need not prove that a defendant knows he is dealing with a weapon possessing every last characteristic which subjects it to regulation. It is enough to prove he knows that he is dealing with a dangerous device of such type as would alert one to the likelihood of regulation. If he has such knowledge, and if the particular item is in fact regulated, he acts at his peril.... It is not necessary for the Government to prove that the defendant knew that the weapon in his possession was a firearm within the meaning of the statute, only that he knowingly possessed it. ${ }^{58}$

However, unlike the situation in Yermian and Liparota, the adverb knowingly does not appear in the statute, which provides simply that it shall be unlawful for any person "to receive or possess a firearm which is not registered to him in the National Firearms Registration and Transfer Record ...."59 The government first inserted the word knowingly in the indictment; the trial court then did the same in the jury instructions. ${ }^{60}$ Nonetheless, the indictment and the jury instruction were "the law" as far as the jury in the trial was concerned, so, for the purposes of the study done in connection with this essay, the linguists analyzed the phrase knowingly possessed a firearm as if the statute so read. ${ }^{61}$

56. 26 U.S.C. $\$ 5845(\mathrm{a}),(\mathrm{e}),(\mathrm{f})(1988)$.

57. 971 F.2d at 612 n.6.

58. Id. at 612 (emphasis omitted). The jury also received this instruction:

A person is knowingly in possession if his possession occurs voluntarily and intentionally and not because of mistake or accident or other innocent reason. The purpose of adding the word knowingly was to insure that no one would be convicted of possession of a firearm if he did Id. not intend to possess it.

59. 26 U.S.C. $\$ 5861$ (d) (1988).

60. It is not entirely clear whether prosecutors and judges routinely add knowingly to the statutory language in stating the elements of this crime on the grounds that Congress intended some intent requirement for the crime and simply neglected to state it, or because constitutional due process requires at least this level of intent. This question is also addressed by the appeals court in Staples. See infra note 67.

61. Because the addition of a knowledge requirement to $\$ 5861$ (d) is in effect an act of judicial legislation, albeit perhaps one performed in order to effect legislative intent, the linguists' analysis is addressed to the courts as it would be to a legislature. In other words, it is up to the Court in the Staples case, like a legislature, to decide the appropriate state of mind requirement. That requirement then should be enacted with minimal ambiguity and maximal comprehensibility for those affected by the enactment. Indeed, the ambiguity of the phrase knowingly possessed a firearm has obscured the state of mind requirement imposed by the various lower courts that have interpreted this provision. See Staples, 971 F.2d at 618-19 (Ebel, J. concurring) (collecting and discussing the various circuit court statements on state of mind required for conviction under $\S 5861(\mathrm{~d})$ ). One might almost suspect that, like legislators on some 
The threshold question of interpretation is whether firearm is to be understood as defined in the National Firearms Act or according to its ordinary meaning. Because possession is an indictable offense only if the item possessed is a firearm within the meaning of the Act, it seems reasonable to begin by assuming that firearm is to be interpreted according to its statutory definition. That definition states that "[t]he term 'firearm' means [among other things]... a machinegun." ${ }^{2}$ Thus the phrase knowingly possessed a machinegun should be legally equivalent to the language of the indictment in this case.

The Staples case presents one instance of a well-studied class of expressions using verbs that describe attitudes. ${ }^{63}$ In ordinary English usage, when we assert that an individual holds an attitude (such as knowing, believing, wanting, or expecting) toward a proposition, we accurately ascribe that attitude to the person only insofar as he himself would recognize that he holds the attitude toward that proposition. For example, suppose Smith knows that Harold Baker is her neighbor. Even if we know that Harold Baker is a judge, we cannot assume Smith knows that her neighbor is a judge. Thus the truth of both (3)(a) and (3)(b) does not entail the truth of (3)(c).

(3)(a) Smith knows that her neighbor is Harold Baker.

(3)(b) Harold Baker is a judge.

(3)(c) Smith knows her neighbor is a judge.

Similarly, if Smith knows that Harold Baker is a judge, but does not know that Judge Baker lives next door to her (for example, she mistakenly thinks her neighbor is a trial lawyer named Arnold), then it still might be correct to assert 3(d).

(3)(d) Smith doesn't know her neighbor is a judge.

Logicians express this idea by the maxim "substitutability of identicals does not preserve truth in opaque contexts." An "opaque context" is a context

occasions, the various courts have taken advantage of this ambiguity to hide the actual import of their action, and in effect impose strict liability in cases like Staples. The addition of knowingly in the indictment thus creates a false impression that conventional standards of criminal culpability have been met when actually the relevant knowledge, that the object is a rifle, implies no wrongful intent.

62. 26 U.S.C. $\$ 5845$ (a) (1988). Machinegun is itself specifically defined in the next part of the statute: The term "machinegun" means any weapon which shoots, is designed to shoot, or can be readily restored to shoot, automatically more than one shot, without manual reloading, by a single function of the trigger. The term shall also include the frame or receiver of any such weapon, any part designed and intended solely and exclusively, or combination of parts designed and intended, for use in converting a weapon into a machinegun, and any combination of parts from which a machinegun can be assembled if such parts are in the possession or under the control of a person.

26 U.S.C. $\$ 5846$ (b) (1988). In contrast to the definition of firearm, the definition of machinegun, at least the first sentence, appears fairly similar to ordinary language meaning.

63. This observation was made by Green, who performed the initial analysis of the Staples case. 
within which different descriptions of the same object cannot be substituted without altering the proposition expressed by the statement. ${ }^{64}$ In our example, "Harold Baker" and "her neighbor" are the equivalent terms which cannot be substituted freely in a sentence about what Smith knows.

Restated in terms applicable to the Staples case, the question is whether a person knows that he possesses an object meeting a particular description (a machinegun) if he knows that he possesses the object, but does not know that it satisfies that description. In the phrase knowingly possessed a

the clause following knowingly is in an opaque context. Presumably the phrase knowingly possessed is equivalent to possessed and knew that he possessed. According to the principles discussed above, the statement Staples knew that he possessed a machinegun is true only if both of the following are true statements at the relevant time:

(4)(a) Staples knows that Staples possesses $X$ and

(4)(b) Staples knows that $X$ is a machinegun.

The only way to make the indictment consistent with the trial judge's explanation of it to the jury is to make the implausible claim that the indictment used the single word firearm with two different meanings in the same sentence. This would amount to treating firearm as meaning simply gun when speaking of what Staples knew, but as meaning machinegun as to what he possessed.

Whether simply knowing that the object in one's possession is a gun is a sufficiently culpable state of mind, either in terms of the intent behind the Act or in terms of due process, is a question beyond the scope of this essay. ${ }^{65}$ The Supreme Court has at least three different options for defining the state of mind required for this crime: (1) conviction if Staples knew he possessed the object, even if he knew nothing about its characteristics; ${ }^{66}(2)$ conviction if Staples knew he possessed the object and knew that it was a gun, even if he thought it was the kind of gun that does not need to be registered; or (3)

64. See, e.g., WILLARD V. QUINE, WORD AND OBJECT 141-56 (1960).

65. The jury instructions themselves indicate that the reason they contain the word knowingly is to distinguish possession that is voluntary and intentional from possession "because of mistake or accident or other innocent reason." See supra note 58. If so, this rationale is inconsistent with an interpretation providing that the possessor need not know the identity of what is possessed to be guilty of illegally and knowingly possessing it. The theory in the jury instructions appears to be that if the object is of a sort that the possessor suspects might be regulated, it is incumbent on her to determine exactly what it is. However, this rationale is insufficient to distinguish intentional and voluntary possession from accidental or mistaken possession. If Smith orders a case of wine, and a wooden crate labelled "Cabernet Sauvignon" is delivered to her house, she has no reason to open it immediately and examine the contents just because wine is a regulated substance. Yet it might contain something else instead of, or in addition to, the wine; it could happen that she was an unwitting conduit for a conspiracy, involving say, her cook and the wine merchant, to import arms and drugs. Surely we would not say she knowingly possessed the contraband, even though she intentionally and voluntarily possessed the box that contained it.

66. Presumably this broadest standard would still result in the acquittal for possession of the M1 carbine. See supra notes 54-55 and accompanying text. 
conviction only if Staples knew he possessed the object and knew that it was a machinegun. ${ }^{67}$

Linguistics contributes to legal understanding by establishing that if the Court opts for either the first or second of these, no subsequent indictment or jury instruction should use the phrase knowingly possessed a firearm because an ordinary language interpretation of the phrase implies a higher level of knowledge. Certainly every effort should be made to draft jury instructions so that they do not contravene ordinary language principles of meaning. Rather, the knowledge requirement should be expressed in a nonambiguous way, as illustrated by Solan's discussion of Yermian and Liparota. $^{68}$

\section{THE CASE OF THE Missing REFERENT: UNITED StATES V. GRANDERSON}

In the second pending Supreme Court case to be discussed in this essay, United States v. Granderson, ${ }^{69}$ we found an interesting parallel to the implausible way the trial court in Staples apparently tried to assign different meanings to the same word in the same sentence. However, in Granderson the problem of interpretation that led to such an implausible reading arose more from the relation between the text and its larger context (the "missing referent" of this Part's heading), than from the words of the text alone.

The defendant in Granderson was charged with destruction of mail, a crime that carries a term of up to six months imprisonment. He pled guilty and the court sentenced him to a term of five years probation, but he violated that probation three months later when his urine sample tested positive for cocaine. The court revoked his probation and sentenced him to a twenty month sentence of imprisonment, based on the following statutory provision:

If the defendant violates a condition of probation at any time prior to the expiration or termination of the term of probation, the court may, after a hearing pursuant to Rule 32.1 of the Federal Rules of Criminal Procedure, and after considering the factors set forth in section 3553(a) to the extent that they are applicable-

(1) continue him on probation, with or without extending the term of [sic] modifying or enlarging the conditions; or

(2) revoke the sentence of probation and impose any other sentence that was available under subchapter $A$ at the time of the initial sentencing.

67. There is a fourth option: conviction only if Staples also knew that machineguns must be registered. However, this last condition relates to a mistake of law, not fact, and the Supreme Court has already decided that conviction under the National Firearm Act does not require proof that the defendant knew that the law required registration of the object. See United States v. Freed, 401 U.S. 601 (1971).

68. For example, if the Court chooses the second option, the indictment could state: "Defendant knowingly possessed an AR-15 assault rifle, knowing that this rifle was a dangerous weapon, although not necessarily knowing that it was a machinegun. Defendant failed to register this rifle."

69. 969 F.2d 980 (11th Cir. 1992), cert. granted, 113 S. Ct. 3033 (1993). 
Notwithstanding any other provision of this section, if a defendant is found by the court to be in possession of a controlled substance, thereby violating the condition imposed by section 3563(a)(3), the court shall revoke the sentence of probation and sentence the defendant to not less than one-third of the original sentence. ${ }^{70}$

The trial court interpreted original sentence as referring to the five-year sentence of probation and ordered imprisonment for twenty months (one-third of sixty months). The Court of Appeals for the Eleventh Circuit reversed and ordered Granderson released from custody, apparently interpreting original sentence to refer to the maximum potential sentence of imprisonment for the original crime (six months). By the time of the appellate decision, Granderson had already been imprisoned for more than eleven months. ${ }^{71}$

In deciding the Granderson case, the Eleventh Circuit joined the Third, ${ }^{72}$ Sixth, ${ }^{73}$ and Tenth $^{74}$ Circuits in limiting the maximum term of imprisonment for a probation violation under the last sentence of $\$ 3565$ (a) to one-third of the maximum potential term of imprisonment for the underlying crime. However, the Eighth ${ }^{75}$ and Ninth $^{76}$ Circuits had interpreted original sentence, as did the trial court, as referring to the term of the probation. The United States successfully petitioned the Supreme Court to grant certiorari to resolve the circuit split. In urging reinstatement of the twenty-month term of imprisonment, the government asserted in its brief to the Court that the rule of lenity is inapplicable because "the language of the statute unambiguously provides that a defendant's sentence of imprisonment ... must be at least onethird as long as the original sentence of probation." 77

When the linguists began to review this statutory provision, it was assumed that the interpretive problem was identifying the referent for original sentence. This initial review produced the observation that there were only two possible interpretations of original sentence, and neither one of them was consistent with that applied by the trial court. ${ }^{78}$ All other things being equal, one would assume original sentence means the sentence that was originally imposed. Since Granderson's original sentence in that sense was sixty months

70. 18 U.S.C. $\$ 3565$ (a) (1988).

71. 969 F.2d at 985 . The Court of Appeals noted that if Granderson had been separately charged for possession of cocaine, 21 U.S.C. $\$ 841$ (a) (1988), he would have faced a statutory maximum of one year imprisonment. 969 F.2d at 983 n.2. Thus, the maximum combined imprisonment that could have been imposed for convictions of both mail destruction and cocaine possession was 18 months; the sanction for violating probation under the mail destruction conviction was 20 months.

72. United States v. Gordon, 961 F.2d 426 (3d Cir. 1992).

73. United States v. Clay, 982 F.2d 959 (6th Cir. 1993), petition for cert. filed, 62 U.S.L.W. 3060 (U.S. July 6, 1993) (No. 93-52).

74. United States v. Diaz, 989 F.2d 391 (10th Cir. 1993).

75. United States v. Byrkett, 961 F.2d 1399 (8th Cir. 1992).

76. United States v. Corpuz, 953 F.2d 526 (9th Cir. 1992).

77. Brief for the United States at 10, Granderson (No. 92-1662).

78. Green performed the initial review of the Granderson case. 
on probation, revoking the sentence of probation and sentencing the defendant to not less than one-third of the original sentence would amount to revoking the sixty months of probation and sentencing the defendant to not less than twenty months of probation. Alternatively, the drafters of the statute might have intended original sentence to refer to the maximum allowable sentence of six months incarceration for the original crime under the sentencing guidelines. The phrase "any other sentence that was available under subchapter A" in the second general condition of $\$ 3563$ apparently refers to this sort of original sentence. ${ }^{79}$ According to this interpretation, "not less than one-third of the original sentence" would be not less than two months incarceration. Those who analyzed the provision felt certain though that there was no linguistic justification based on the text for the trial court's decision, since that interpretation selected one interpretation of sentence for the type of punishment (incarceration) and a different interpretation for the term of that punishment (one-third of the probation period).

Upon further reflection, we conclude that the interpretive problem with original sentence is not ambiguity as to which prior referent is meant; rather, original sentence has no contextually identifiable referent. So whatever the contested provision means, its meaning is not plain as a matter of ordinary language and it requires extratextual sources for interpretation.

Our analysis then shifted to the lexical ambiguity of sentence as a technical term in this statute. ${ }^{80}$ When Congress passed the Sentencing Reform Act of 1984, it altered the conventional meanings of sentence and probation. The provision at issue was not part of the 1984 Act but was added to $\$ 3565$ (a) by the Anti-Drug Abuse Act of $1988 .{ }^{81}$ Prior to the 1984 Act, sentence in the context of criminal conviction referred to the imposition of imprisonment, fine, or both. Probation was understood to be an alternative to sentencing. ${ }^{82}$ Thus, the Federal Probation Act of 1925 referred to the court's power to "suspend the imposition or execution of sentence and to place the defendant upon probation." 83 The 1984 Act, however, made probation a type of sentence. The Committee Report accompanying the Act explained that under the new law "unlike current law . . probation is a type of sentence rather than a suspension of the imposition or execution of a sentence." 84 The first section of the Chapter on Sentencing in Title 18 of the U.S. Code states in relevant part: "An individual found guilty of an offense shall be sentenced . . . to: (1)

79. Cf. 18 U.S.C. $\$ 3742$ (a)(3) (review of sentence) in which the phrase sentence specified in the applicable guidelines refers to the maximum sentence that could be imposed under the guidelines.

80. For a useful survey of different views of what distinguishes technical language, especially in law, see Mary J. Morrison, Excursions into the Nature of Legal Language, 37 CLEV. ST. L. REV. 271 (1989).

81. Pub. L. No. 100-690, 102 Stat. 4181.

82. Corpuz, 953 F.2d at 528.

83. Pub. L. No. 596, 43 Stat. 1259.

84. S. ReP. No. 225, 98th Cong, 2 d Sess. 88 (1983), quoted in Corpuz, 953 F.2d at 528-29. 
a term of probation ... (2) a fine ... or (3) a term of imprisonment ...."85 These three different types of sentence will be referred to as sentence ${ }^{P}$ (probation), sentence ${ }^{F}$ (fine), and sentence $e^{l}$ (imprisonment).

The first occurrence of sentence in the relevant provision ${ }^{86}$ is sentence $^{P}$ : sentence of probation. The other two occurrences of sentence in the provision, the verb phrase "sentence the defendant" and the last phrase "one-third of the original sentence" lack a modifier explicitly indicating whether sentence refers to probation, imprisonment or fine. Without regard to the context, the most obvious interpretation would be that sentence in the balance of the provision also refers to sentence $e^{P}$. However, the provision would then be interpreted as follows: "the court shall revoke the sentence of probation and sentence the defendant to a term of probation not less than one-third of the original sentence of probation." This meaning is improbable in context because it represents no increased sanction for the possession of a controlled substance. The Eleventh Circuit appeared to interpret the latter two occurrences of sentence as sentencel, so that it would read this way: "and sentence the defendant to a term of imprisonment not less than one-third of the original sentence of imprisonment. ${ }^{\text {"87 }}$ Unfortunately for this interpretation, there was no "original sentence of imprisonment." This forced the Eleventh Circuit to interpret original sentence as if the provision read: "one-third of the maximum sentence of imprisonment that was available at the time of sentencing."

The trial court and the Ninth and Tenth Circuit courts have produced an even stranger interpretation. They interpret the provision as if it read "the court shall revoke the sentence of probation and sentence the defendant to a term of imprisonment not less than one-third of the term of the original sentence of probation," shifting the meaning of sentence from sentence ${ }^{P}$ to sentence $e^{I}$ and then back to sentence ${ }^{P} .^{88}$ This shift in meaning is as linguistically peculiar as the way in which the Staples trial court seemed to switch from gun to machinegun in interpreting firearm in one sentence. We felt confident that there was a linguistically more plausible way to resolve the case of the missing referent for original sentence, and so turned to a review of the way sentence is used throughout the chapter on sentencing in the U.S. Code.

85. 18 U.S.C. \$ 3551(b) (1988).

86. By "relevant provision" we mean the last sentence of 18 U.S.C. $\$ 3565$ (a) (1988). To avoid confusion, we will use the word provision rather than sentence to refer to this sentence.

87. This interpretation assumes that sentence has a default meaning of sentence $e^{l}$ when unmodified. However, with the exception of this provision, the chapter on sentencing, Chapter 227, assiduously avoids unmodified use of sentence, thus suggesting strongly that no default meaning should be assumed. See infra notes 90-91 and accompanying text.

88. Similar terminology appears in the preceding subsection, 18 U.S.C. $\$ 3565(a)(2)$, thus making the Eleventh Circuit's ruling even less plausible as a matter of textual interpretation. Congress showed that it knew how to distinguish between the sentence actually imposed and the potential range of imprisonment available at the time of sentencing. 
Review of the entire text of the chapter on sentencing produces the following observation. ${ }^{39}$ The provision at issue in Granderson is the only place in the entire chapter where sentence appears as the verb in a clause without a modifier to indicate which of the three meanings is intended. Everywhere else Congress was scrupulously careful not to use sentence without modification. ${ }^{90}$ Indeed the Chapter seems to reflect a strong preference for using the verb phrase "imposed a sentence of ___ " rather than simply sentenced. This provision is also the only place in the entire chapter where the phrase original sentence appears. It is as if a speaker of another dialect-the pre-1984 language of sentencing-had interrupted Chapter 227 to utter the statutory language at issue. The provision only seems to make sense under the pre-1984 meanings of probation and sentence, in which an original sentence would always be a sentence of imprisonment that was suspended if the defendant was "placed on" probation. Thus, analysis of the textual language by a linguist in this case seems to point toward an examination of legislative history, particularly a search for evidence that this provision, added in 1988, might have been drafted with the pre-1984 meanings in mind. A review of the legislative history reveals that the provision was literally a last-minute amendment that did not go through the normal committee process and thus might have been framed without an awareness of the new meaning of probation as a type of sentence in the federal scheme. ${ }^{91}$

89. We reviewed Chapter 227 of Title 18 by downloading its text from the LEXIS database, converting it to the WordPerfect word processing software, and then using the "Search and Replace" function to bold and capitalize every word containing the string "sentenc." This process took only a few hours and review of every occurrence in this text of some version of sentence was quite easy. This modified version of the text of Chapter 227 is on file with the authors.

90. The standard verb phrase is "sentenced to a term of (probation or imprisonment)." See, e.g., 18 U.S.C. $\$ \S 3561(a), 3581$ (a), 3583(a) (1988).

91. Cunningham examined this legislative history with the assistance of reference librarian Peggy McDermott. This provision apparently first appeared in a floor amendment in the Senate, after the bill had passed the House, and only one day before the bill passed the Senate. 134 CONG. REC. S15,781 (Oct. 13, 1988) (Byrd Amendment No. 3677 to H.R. 5210). The Anti-Drug Abuse Act of 1988 was a massive and complex piece of legislation, which takes up 364 pages in Statutes at Large, Pub. L. No. 100-690, 102 Stat. $4181-4545$ (1988). The provision may have originated in the following amendment, proposed ten days earlier, which was not enacted into law:

Section 3565(a) of title 18, United States Code, is amended by adding at the end thereof the following: Notwithstanding any other provision of this section, if the defendant tests positive for illegal use of controlled substances, thereby violating the condition imposed by section 3563(a), on two separate tests taken at least 3 weeks apart, the court shall, in addition to any other action which may be taken pursuant to this section (A) revoke the sentence of probation and sentence the defendant to a period of imprisonment, (B) require the defendant to reside and participate in a residential community treatment center program, or participate in an out-patient drug treatment program if residential treatment is unavailable or impractical, or (C) require the defendant to remain at his place of residence pursuant to section $3563(\mathrm{~b})(20)$. Notwithstanding any other provision of this section, if the defendant tests positive for the illegal use of controlled substances, thereby violating the condition set forth in section $3563(a)$ or $(e)$, on three separate tests taken at least 3 weeks apart, the court shall revoke the sentence of probation and sentence the defendant to not less than one third of the original sentence.

134 CoNG. REC. S14,337 (Oct. 3, 1988) (Byrd Amendments Nos. 3369 and 3370) (emphasis added). The same set of amendments also contained, in a section having to do not with drug abuse but with use of an explosive in the commission of a felony, the following pre-1984 use of probation: "Notwithstanding any 
It is striking that neither the briefs of the parties before the Supreme Court nor any of the five circuit court opinions interpreting this provision reflect awareness of this particular aspect of the provision's legislative history. The fact that analysis by a linguist in this case, limited as it is to the four corners of the text, generates a useful clue for searching legislative history is a reminder that close attention to text is not necessarily at odds with the use of legislative history in statutory interpretation.

\section{Deceptive Appearances of Plainness: Ambiguous Noun Phrases}

The potential value of linguistic explication is even clearer in Solan's ingenious explanation of Sedima, S.P.R.L. v. Imrex Co., ${ }^{92}$ in which the nine Justices of the Supreme Court agreed that a statutory provision was unambiguous and yet split five to four as to its plain meaning. Sedima called for interpretation of the federal Racketeer Influenced and Corrupt Organizations Act (RICO). ${ }^{93}$ RICO is Solan's favorite source of examples, as he "can think of no better source of disagreement over the meaning of words in a statute than . . RICO." ${ }^{\prime 94}$ Although RICO is primarily a criminal statute, $\S 1964$ provides a civil remedy of treble damages to "[a]ny person injured in his business or property by reason of a violation of section 1962." Section 1962, in turn, prohibits "any person employed by or associated with any enterprise ... [from conducting] such enterprise's affairs through a pattern of racketeering activity." violated $\S 1962$ by submitting inflated bills under a sales contract; its use of the mails and the telephone to submit the inflated bills constituted federal mail and wire fraud. Mail and wire fraud are both found within RICO's definition of "racketeering activity." decision of the lower courts, in favor of Imrex, holding that injury "by reason of a violation of section 1962" must be more than ordinary business loss due to the inflated billing. Rather, Sedima had to show a "racketeering injury," an injury "different in kind from that occurring as a result of the predicate acts themselves, or not simply caused by the predicate acts, but also caused by an activity which RICO was designed to deter." ${ }^{\prime 98}$

Writing for the majority of five, Justice White said:

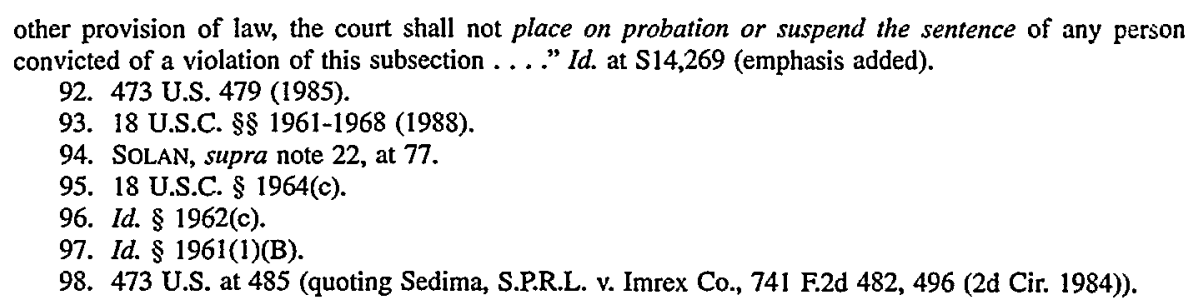


If the defendant engages in a pattern of racketeering activity in a manner forbidden by [ $\$ 1962$ (a)-(c)], and the racketeering activities injure the plaintiff in his business or property, the plaintiff has a claim under $\$ 1964$ (c). There is no room in the statutory language for an additional, amorphous "racketeering injury" requirement.

On behalf of himself and three other dissenters, Justice Marshall wrote:

[T] he statute clearly contemplates recovery for injury resulting from the confluence of events described in § 1962 and not merely from the commission of a predicate act. The Court's contrary interpretation distorts the statutory language under the guise of adopting a plainmeaning definition, and it does so without offering any indication of congressional intent that justifies a deviation from what I have shown to be the plain meaning of the statute. ${ }^{100}$

Solan suggests that subtle ambiguity in the phrase pattern of racketeering activity may explain how the majority and dissenters could come to opposite interpretations of a provision that all thought had a plain meaning. ${ }^{101}$ Solan begins with some ordinary language examples of this type of ambiguity:

(5) A series of rainstorms damaged the house.

(6) A gang of teenagers intimidated the neighbors. ${ }^{102}$

Does the first sentence mean that there were a number of rainstorms, each of which damaged the house, or that the damage only resulted from the cumulative effect of the storms? Does the second mean that various gang members acting individually committed acts of intimidation, or that the teenagers appeared in a group and intimidated the family by their numbers? ${ }^{103}$

Solan explains this ambiguity in terms of a semantic regularity that linguists have observed in certain complex noun phrases of the form "a noun 1 of noun 2," such as a series of rainstorms or a gang of teenagers, where noun 1 can be understood as one type of quantifying expression. In these noun phrases, the expression is ambiguous as to which one of the two nouns is the semantic "head" of the phrase, and which one is the modifier. ${ }^{104}$ If noun 1 is the head, then noun 2 modifies it: it is the series that damages the house and

99. 473 U.S. at 495.

100. Id. at 509-10 (Marshall, J., dissenting).

101. SOLAN, supra note 22, at 102-03.

102. Id. at 102 .

103. Id.

104. Solan cites Elisabeth Selkirk, Some Remarks on Noun Phrase Structure, in FORMAL SYNTAX 285 (Peter W. Culicover et al. eds., 1977), on this point. SoLAN, supra note 22, at 102 n.29. Normally, the modifier would follow the head, as in these unambiguous examples: a child of royalty, an error of logic, or a mirror of the soul. 
rainstorms explains what kind of series it is, or it is the gang that intimidates, and teenagers tells what kind of gang. If noun 2 is the head, then noun 1 is the modifier: it is rainstorms that damage the house, and series adds the information that the storms came one after another; it is teenagers themselves who intimidate, and gang adds information about the connections among the teenagers. Solan terms the interpretation of noun 1 as head the "nondistributive reading," and noun 2 as head, the "distributive reading." 105 For the latter, the action, the damaging or the intimidating, is "distributed" among all the members of the set rather than attributed to them acting collectively.

Solan then applies this analysis to Sedima. Let $\$ 1964$ be paraphrased $^{106}$ as follows: "If an enterprise's pattern of racketeering activity injures a person's business, the injured person may sue for treble damages." The majority used a distributive reading, interpreting activity as the head of the phrase "pattern of racketeering activity." Thus, to state a civil RICO claim, Sedima needed only to show that Imrex's activity of mailing inflated bills inflicted the injury. The dissenters resolved the ambiguity in the other direction: pattern was the head of the phrase for them. They would have required Sedima to show how a pattern of racketeering inflicted injury.

The ambiguity is apparent once explicated by Solan. Absent this linguistic explication, one could easily assign a single interpretation to this subtle ambiguity either way without recognizing what one had done. Once a reader interprets one of the nouns as head of the phrase, the sentence seems "plain" in that it appears to have only one possible interpretation. Without one's own interpretive process being brought to conscious awareness, one could understandably conclude that those offering the other interpretation either do not know how to read or are being intellectually dishonest. Solan does not indicate his view as to which resolution of the ambiguity conforms better with ordinary language expectations. ${ }^{107} \mathrm{He}$ stops at the point of showing that, contrary to the rhetoric of both sides in Sedima, the language is not clear. Nonetheless, his analysis might have improved the discourse of the Court in Sedima had it been available to the Justices. Perhaps they could have agreed that plain meaning did provide guidance, to the extent that analysis of the ordinary language meaning of the phrase revealed a two-way ambiguity typical of certain noun phrases. They might then have relied more explicitly upon

105. Id. at 102.

106. A potential criticism of Solan's analysis of Sedima is that he constructs the ambiguity by importing the noun phrase "pattern of racketeering activity" from \$ 1962 into the sentence being interpreted, $\$ 1964$. Strictly speaking, $\$ 1964$ as written does not present a noun phrase ambiguity problem. But the paraphrase is a fair rewriting of $\$ 1964$, which incorporates $\S 1962$ by reference. 18 U.S.C. $\S \S 1962,1964(\mathrm{c})$.

107. Solan does suggest that the "more natural" reading of the gang example is the nondistributive one, that it was the whole group that was intimidating, but he provides no clear explanation for that choice. He suggests that "the contextual relationship between the group term and the predicate" is a decisive factor. He does not offer a view as to the better reading of the rainstorm example. SoLAN, supra note 22, at 102. 
interpretative strategies other than appeal to ordinary language to resolve that choice. At the very least, Solan's analysis shows how seemingly plain language can create a hard case even at the level of ordinary language comprehension. Indeed, the apparent inability of linguistic principles alone to resolve the ambiguity helps explain why Sedima presented the kind of case worthy of Supreme Court attention.

\section{CONCEPTS WITH FUZZY BOUNDARIES}

Solan distinguishes the types of interpretative problems represented by the cases discussed above in Parts II through V from what he terms "categorical indeterminacy" or "fuzziness." Categorical indeterminacy, he claims, accounts "for most of the problems that arise in the legal context" over the meaning of textual language: "The problem arises ... when a statute or other legal document makes reference to a category of things or events, and a dispute arises over whether a particular thing or event in question fits into the category." ${ }^{103}$ Solan identifies familiar word challenges from philosophy of language (such as defining the categories of game and mountain) and from jurisprudence (such as defining the vehicles prohibited from a park) as being attributable to this problem. ${ }^{109} \mathrm{He}$ seems to conclude that linguistics is capable merely of flagging the indeterminacy of such words but not of assisting judges in resolving that indeterminacy. He illustrates this argument with further discussion of RICO cases.

Solan effectively distinguishes ambiguity that presents a clear choice between meanings from the problem of fuzzy conceptual boundaries by returning to the same phrase, pattern of racketeering activity, discussed in Part $\mathrm{V}$ in relation to the Sedima case. Four years after deciding Sedima, the Supreme Court returned to this phrase to determine the meaning of pattern. In H.J. Inc. v. Northwestern Bell Telephone Co., ${ }^{110}$ the issue was whether a single scheme to bribe state officials could constitute a pattern of racketeering activity where the alleged bribery involved multiple acts over a period of time. Both the trial court and the court of appeals had agreed that a pattern required proof of at least two different racketeering schemes. ${ }^{111}$ Once again, the Court split five to four, although all of the Justices voted for reversal. Writing for the majority, Justice Brennan set out the following definition based on "a commonsense, everyday understanding of RICO's language:"112

108. Id. at 96.

109. Id. (game example drawn from LudWIG WITTGENSTEIN, PhILOSOPHICAL INVESTIGations 31-32 (1953); mountain from QUINE, supra note 64, at 126; and vehicle from H.L.A. HART, THE CONCEPT OF LAW 125-26 (1961)).

110. 492 U.S. 229 (1989).

111. Id. at 233-35.

112. Id. at 241. 
[T]o prove a pattern of racketeering activity a plaintiff or prosecutor must show that the racketeering predicates [e.g. acts of bribery] are related, and that they amount to or pose a threat of continued criminal activity. . . . Predicate acts extending over a few weeks or months and threatening no future criminal conduct do not satisfy this requirement. ${ }^{113}$

He concluded that the plaintiff's allegations met this less stringent definition of pattern and reinstated its RICO complaint. Concurring, Justice Scalia agreed that RICO does not require proof of multiple racketeering schemes, but suggested that RICO's language might be so indeterminate as to be unconstitutional under the "void for vagueness" doctrine, a problem that in his view the majority's definition did not cure. ${ }^{114}$

Solan offers two linguistic criticisms of the majority's definition of pattern. First, he questions whether the requirement that acts take place over a long period of time is soundly based on a "commonsense, everyday understanding" of pattern, as the majority claimed. He argues that "there is nothing in the word 'pattern' that requires continuity, except for a period long enough to permit formation of the pattern itself." 115 He gives the following two uses of pattern which seem perfectly acceptable even though the events took place over a much shorter time period than the majority opinion would allow:

During the three weeks that he was on drugs, John exhibited a pattern of violent behavior that we had not seen before and have not seen since.

The two-week outburst of burnings formed a pattern: only buildings that had not been occupied for two months were torched. ${ }^{116}$

Second, he characterizes the majority definition of pattern as requiring "relatedness plus continuity" among the predicates. ${ }^{117}$ But, he argues, "relatedness is at least as indeterminate a concept as is patternhood . . . . Try, as an experiment, to define relatedness meaningfully so that your definition has predictive force. You will fail." ${ }^{118} \mathrm{He}$ draws the following conclusion:

Justice Brennan's effort to divine a 'common-sense, everyday understanding' of the statute from its language is actually an effort to decompose the word 'pattern' into what he apparently believes are its

113. Id. at 239,242 (emphasis added).

114. Id. at 255-56 (Scalia, J., concurring in the judgment).

115. SOLAN, supra note 22 , at 105.

116. Id.

117. Id.; see Northwestern Bell, 492 U.S. at 239 (emphasis added). The Court may have derived this formula from the legislative history. See id. (citing 116 CONG. REC. 18,940 (1970) (statement of Sen. McClellan, the bill's sponsor)); Sedima, S.P.R.L. v. Imrex Co., 473 U.S. 479, 496 n.14 (1985).

118. SOLAN, supra note 22 , at 105. 
component concepts. The effort fails, as do most efforts at lexical decomposition. ... Nor would it do to substitute other concepts for relatedness and continuity. Exactly the same types of problems would arise. We will always be able to find examples of patterns and nonpatterns that challenge the proposed components.

The problems that the Court faced in construing the word "pattern" in RICO are, in fact, unavoidable. They result from the imperfect match between concepts conveyed by the words in a statute and the virtually infinite variety of events that can occur in the world. As hard as we may try to avoid the indeterminacy of concepts at the margins, we will not succeed. ... Our knowledge of language ... simply does not answer all of these questions. ${ }^{119}$

Solan continues this approach to category indeterminacy with a discussion of yet another RICO case, United States v. Turkette, ${ }^{120}$ in which the meaning of enterprise was at issue. Relying heavily on statements in the legislative history indicating that the purpose of RICO was to prevent organized crime from infiltrating legitimate business enterprises, the court of appeals had held that enterprise could not apply to organizations that are exclusively criminal. In reversing, the Supreme Court emphasized the importance of plain meaning:

In determining the scope of a statute, we look first to its language. If the statutory language is unambiguous, in the absence of "a clearly expressed legislative intent to the contrary, that language must ordinarily be regarded as conclusive....

The Court of Appeals, however, clearly departed from and limited the statutory language....

If Congress had intended the more circumscribed approach espoused by the Court of Appeals, there would have been some positive sign that the law was not to reach organized criminal activities .... The language of the statute, however-the most reliable evidence of its intent-reveals that Congress opted for a far broader definition of the word "enterprise," and we are unconvinced by anything in the legislative history that this definition should be given less than its full effect. ${ }^{121}$

Solan's critique of this statement by the Court is equally strong:

[I]t is wrong to say that "enterprise" could not be understood to include only legitimate businesses. Generally speaking, that is how the

119. Id. at 105-06.

120. 452 U.S. 576 (1981).

121. Id. at 580-81, 593 (citation omitted). 
word is used, and the statute's definition is not really very helpful. . . .

....

... [T] "enterprise" means in RICO. While we do have a sense of a typical enterprise, I would be extremely hard pressed to state the necessary and sufficient conditions for membership in the class of enterprises.

...

... [Enterprise $]$ becomes a fuzzy concept at the margins. ${ }^{122}$

Given that Solan characterizes the problem of "fuzzy boundaries" as the most common source of hard cases arising from textual interpretation, we were naturally intrigued by his position that the inadequacies of the decisions in Northwestern Bell and Turkette were "unavoidable," presumably even with the assistance of linguistics. Thus we were delighted when one of the pending Supreme Court cases identified in our review of cases to be argued in December 1993 and January 1994 not only involved a problem of categorization, but also concerned the very word enterprise in RICO. We did indeed find that the puzzle of enterprise presented different kinds of interpretive challenges than the texts in Staples and Granderson, as evidenced by our decision to undertake several empirical research projects as part of our analysis of that puzzle. By the end of Part VI, however, we reach a more optimistic conclusion than Solan about the potential contribution linguistics can make to solving the apparent problem of the "fuzzy boundaries" of categories referenced by words in legal texts.

\section{THE PUZZLE OF ENTERPRISE}

\section{A. The NOW Case $e^{123}$}

In 1986 the National Organization for Women (NOW), together with two women's health centers, filed a civil suit against the Pro-Life Action Network (PLAN) and a number of other anti-abortion organizations and individual activists, claiming in part that PLAN had violated RICO through its nationwide campaign to close medical clinics that provide abortion services. The specific provision of RICO invoked by NOW provides:

It shall be unlawful for any person employed by or associated with any enterprise engaged in, or the activities of which affect, interstate or foreign commerce, to conduct or participate, directly or indirectly,

122. SolAN, supra note 22 , at $79,107$.

123. National Org. for Women v. Scheidler, 968 F.2d 612 (7th Cir. 1992), cert. granted, 113 S. Ct. 2958 (1993), rev'd, 114 S. Ct. 798 (1994). 
in the conduct of such enterprise's affairs through a pattern of racketeering activity or through collection of an unlawful debt. ${ }^{124}$

NOW sought monetary damages and an injunction ${ }^{125}$ to prevent PLAN and the other defendants from engaging in such criminal activities as trespass, vandalism, and extortion. ${ }^{126}$ The trial court dismissed the complaint for failure to state a claim, ${ }^{127}$ and the Court of Appeals for the Seventh Circuit "reluctantly" affirmed the dismissal. ${ }^{128}$ The Supreme Court granted NOW's petition for certiorari only as to one of the grounds for dismissal: that PLAN was not an enterprise within the meaning of $\S 1962$ (c) and (d) of RICO. ${ }^{129}$ The Seventh Circuit applied the following definition of enterprise: "an association having an ascertainable structure which exists for the purpose of maintaining operations directed toward an economic goal that has an existence that can be defined apart from the commission of the predicate acts constituting the pattern of racketeering activity." 130 Because this widely cited definition of enterprise apparently entered RICO case law through the Eighth Circuit's opinion in United States v. Anderson, we will refer to it as the "Anderson definition."

NOW, the United States as amicus supporting NOW's position, and the RICO defendants each argue in their briefs to the Supreme Court that the plain meaning of the statute is unambiguous and directs a decision in their favor. Both NOW and the government start their briefs by asserting that because enterprise is defined in the statute, no further inquiry (into the legislative history or otherwise) is necessary. ${ }^{131}$ However, it is apparent upon reading the definitional section of RICO, $\S 1961$, that the subsection on enterprise does not state what conditions must be satisfied for something to count as an enterprise: "'[E]nterprise' includes any individual, partnership, corporation, association, or other legal entity, and any union or group of individuals

124. 18 U.S.C. $\$ 1962$ (c) (1988) (emphasis added). NOW also alleged violation of 18 U.S.C. $\S$ 1962(d), which prohibits conspiracy to violate $\S 1962$ (c).

125. NOW filed the suit seeking to represent a nationwide class of women seeking abortion services, and the two health centers acting as name plaintiffs sought to represent a class of all health centers seeking to perform abortions; the motions for class certification were not decided prior to dismissal.

126. The plaintiffs alleged that PLAN members committed the predicate acts of "racketeering" required for RICO by violating the Hobbs Act, 18 U.S.C. \& 1951 (1988).

127. 765 F. Supp. 937 (N.D. Ill. 1991).

128. 968 F.2d at 614 .

129. The Court granted certiorari on the question of whether "[i]n addition to [the] statutory "interstate commerce' and injury to one's 'business or property' requirements of RICO, should [the] statute be further limited to cases in which either [the] enterprise or predicate acts has an overriding economic motive?" 62 U.S.L.W. 3027 (U.S. July 20, 1993) (No. 92-780).

130. NOW, 968 F.2d at 627 (emphasis added) (quoting United States v. Anderson, 626 F.2d 1358, 1372 (8th Cir. 1980), cert. denied, 450 U.S. 912 (1981)).

131. Presumably, if enterprise were in fact given a comprehensive technical meaning by statutory definition, ordinary language usage would be of less relevance. See supra text accompanying note 56 (definition of firearm). 
associated in fact although not a legal entity." ${ }^{\prime 132}$ Despite occurring in a section entitled "Definitions," this statement does not define enterprise, precisely because it does not state necessary and sufficient conditions for something to be an enterprise. NOW and the government argue as if the passage began "Enterprise means" rather than "Enterprise includes." Section 1961 does define other terms using "means." ${ }^{.133}$ If Congress intended for includes to be interpreted as means, then anything that fits within one of the categories listed after includes would count as an enterprise. Most obviously, such an interpretation would entail that every individual is an enterprise. Inasmuch as $\S 1961$ does use different verbs in defining other words, it is reasonable to assume that includes has a different import than means in that section, just as it does in ordinary language. Subsection 1961(4) on enterprise seems to assume that the reader already has an understanding of what an enterprise is, and to instruct the reader that nothing should preclude considering the listed types of entities as possible enterprises pursuant to that understanding. In particular, $\$ 1961(4)$ seems intended as a corrective against the possibility that the reader's preexisting understanding of enterprise might cause her to limit the word to legally constituted entities like corporations and partnerships. ${ }^{134}$

A plain meaning interpretation of enterprise thus cannot begin and end with the definition section of the statute. Because RICO's so-called definition of enterprise contains so little information, there seems to be little evidence to rebut the normal presumption in statutory interpretation, often applied in RICO cases, that Congress intended the ordinary meaning of the words used. ${ }^{135}$ Thus, attempting to buttress its statutory definition argument, NOW next turns in its brief to Webster's Third New International Dictionary for this definition: "'Enterprise' encompasses any 'venture, undertaking, project' or 'any systematic purposeful activity or type of activity.' Based on this definition, NOW argues that in "its normal usage, 'enterprise' includes virtually any type of organized venture."136 One group of RICO defendants rejoins by quoting the same dictionary:

But RICO clearly does not incorporate this meaning of 'enterprise'; the statutory definition includes entities, not mere 'activities' or 'designs.' The first concrete definition given for an enterprise is as

132. 18 U.S.C. § 1961(4) (1988).

133. E.g., id. § 1961(1) (““[R]acketeering activity' means ...."); id. § 1961(6) (““[U]nlawful debt' means ....").

134. Subsection 1961(4) was used by the Court this way in United States v. Turkette, 452 U.S. 576, 580-82 (1981), to hold that enterprise can apply to an illegal association, in particular, an arson ring.

135. See Russello, 464 U.S. at 21 (construing ordinary meaning of the term interest in RICO).

136. Brief of Petitioners at 21-22, NOW, 114 S. Ct. 798 (1994) (No. 92-780) (quoting WeBsTER's TAIRD NEW INTERNATIONAL DICTIONARY 757 (unabr. 1971)). 
follows: 'a unit of economic organization or activity (as a factory, a farm, a mine); esp: a business organization: FIRM, COMPANY., ${ }^{137}$

However, the dictionary widely regarded as most extensive and authoritative, the Oxford English Dictionary (Second Edition) does not list "unit of economic activity," "business organization," "firm," "company," or any similar term in its definition of enterprise. ${ }^{138}$ This difference does not seem to be attributable to variation in dialect between British and American English; several American dictionaries, including Webster's Second Edition, do not list "business" or an equivalent for enterprise. ${ }^{139}$ Also problematic for the RICO defendants' reliance on dictionary definition would be this definition from yet another dictionary: "any undertaking; project: a business enterprise." 140 This definition treats "business" as an example of a much more expansive category that by its terms-“"any undertaking"-could well include PLAN.

Recourse to dictionaries is a notable feature of the "new textualism"; ${ }^{141}$ and the Court has relied upon them before in interpreting RICO. ${ }^{142}$ However, as this variance among well-known dictionaries illustrates, such reliance must be very guarded. It is tempting to expect to resolve disputes about the "plain meaning" of a word by invoking a dictionary definition that purportedly reveals what the word "properly" means. It is commonly supposed that dictionaries represent facts of the language that are independent of the users of the language, and that if a usage does not conform with the description in the dictionary, the usage is incorrect. This is a misconception, as discussed in further detail in the conclusion of this essay. ${ }^{143}$

Unlike the briefs before the Supreme Court, the reasoning of the Seventh Circuit opinion in NOW relies neither on statutory nor dictionary definitions in concluding that enterprise means an association "directed toward an economic goal." ${ }^{144}$ Rather, the court relies on RICO case law. The court cites

137. Brief of Respondents Randall A. Terry, Project Life, and Operation Rescue at 20, NOW, 114 S. Ct. 798 (1994) (No. 92-780) (quoting WEBSTER's THIRD NEW INTERNATIONAL DICTIONARY 757 (unabr. 1986) (emphasis and capitalization in the dictionary quotation)). For a more complete quotation of this definition, see infra Appendix A. This brief makes the same point about the significance of the use of the word includes rather than means in the statutory definition as presented above, see supra text accompanying note 132 . This brief is the only place we have seen this seemingly obvious distinction recognized.

138. See infra Appendix A for this and eight other dictionary definitions of enterprise.

139. See infra Appendix A (definitions from Funk \& Wagnall's New Standard Dictionary, Webster's New Twentieth Century Dictionary, and Webster's New World Dictionary of the American Language). The Oxford Encyclopedic English Dictionary does list "business firm" in its definition.

140. See infra Appendix A (definition from The World Book Dictionary).

141. See, e.g., Chapman v. United States, 111 S. Ct. 1919, 1926 (1991) (dictionary definitions of mixture); Board of Educ. of Westside Community Sch. v. Mergens, 110 S. Ct. 2356, 2365 (1990) (definition of curriculum); Chan v. Korean Air Lines, Ltd., 490 U.S. 122, 128 (1989) (definition of irregularity). See generally Lawrence Solan, When Judges Use the Dictionary, 68 AM. SPEECH 50 (1993).

142. See Russello v. United States, 464 U.S. 16, 21 (1983).

143. See infra text accompanying notes 197-204.

144. NOW, 968 F.2d at 627 (quoting United States v. Anderson, 626 F.2d 1358, 1372 (8th Cir. 1980)). 
Northwestern Bell ${ }^{145}$ as authority for the interchangeability of business and enterprise for RICO purposes. However, interchangeability of two words in a particular context does not mean that they are synonymous. For example, one word (business) may refer to a subcategory or example from a larger category encompassed by the other word (enterprise). The Seventh Circuit also relies heavily on the Anderson decision and subsequent cases applying it. Unfortunately the Anderson definition is muddled both in origin and in application. The Anderson opinion, although thorough and scholarly in many respects, provides very little explanation ${ }^{146}$ for the "economic goal" part of its definition, which is not surprising since that requirement is entirely dicta in the Anderson case itself. The alleged enterprise in Anderson was a group of three people - two county administrators and a salesman —operating a kickback scheme for county purchases of various highway supplies. The "economic goal" requirement was dicta because the defendants never argued that the alleged enterprise lacked an economic goal; the three participants obviously intended to make money through their scheme. ${ }^{147}$ Since the Anderson decision in 1980, its definition of enterprise has been widely cited but rarely with any discussion or effect on case outcome. Indeed, in a number of cases that appear to adopt the Anderson definition, the alleged RICO enterprise is a government agency, most frequently a police department, a unit of local government, or a court. Yet not one of these cases acknowledges that it is peculiar to define a government agency, particularly a court or police department, as an association that directs its operations toward an "economic goal." 148

145. Id. at 629 (citing 492 U.S. at 229). See supra notes 110-19 and accompanying text for discussion of Northwestern Bell.

146. The Anderson court does quote a law review article by Senator McClellan, a cosponsor of the Act, and a law review note to the effect that "the purpose" of RICO is "economic." 626 F.2d at 1368 (quoting John L. McClellan, Organized Crime Control Act (S. 30) or Its Critics: Which Threaten Civil Liberties?, 46 NOTRE DAME L. REV. 55, 161-62 (1970), and Note, Organized Crime and the Infiltration of Legitimate Business: Civil Remedies for "Criminal Activity," 124 U. PA. L. REv. 192, 222 (1975)).

147. The Anderson court emphasized the narrow scope of its decision: "Defendants . . argue that the term 'enterprise' does not encompass an illegal association that is proved only by facts which also establish the predicate acts constituting the "pattern of racketeering activity.' This is the narrow issue we address." 626 F.2d at 1365; see also id. at $1365 \mathrm{n} .10$. The Eighth Circuit held that this association of three people was not an enterprise because it had no existence independent of the kickback scheme itself. It is noteworthy that in so holding, the Eighth Circuit explicitly rejected a "plain meaning" approach to interpreting the meaning of "enterprise" (an approach the court seemed to assume would result in finding the association to be an enterprise) and invoked legislative history in support of its holding. 626 F.2d 137072.

148. Perhaps the most striking example is the Seventh Circuit's decision in United States v. Neapolitan, 791 F.2d 489 (7th Cir. 1986), cited by the NOW court as its immediate precedent. Neapolitan was a police officer who allegedly collected protection money from car thieves. Thus the alleged enterprise within which he conducted his racketeering activities was his place of employment, the county sheriff's department. Id. at 492. The defendant apparently never argued that lack of economic goal on the part of the claimed enterprise defeated the RICO claim. For other cases in which the RICO enterprise was a governmental unit, see United States v. Hocking, 860 F.2d 769, 778 (7th Cir. 1988); United States v. Yonan, 800 F.2d 164, 167-68 (7th Cir. 1986), cert. denied, 479 U.S. 1055 (1987); United States v. De Peri, 778 F.2d 963, 975 (3d Cir. 1985), cert. denied, 475 U.S. 1110, cert. denied, 476 U.S. 1159 (1986); United 
Indeed, apart from the NOW decision itself, there appears to be only one reported appellate decision applying the Anderson definition to find that an entity was not a RICO enterprise because it lacked an economic goal. In United States v. Ivic, in an opinion by Judge Friendly, the Second Circuit held that a group of Croatians organized for the purpose of carrying out terrorist activities was not an enterprise because its goals were political, not economic: "Defendants joined together not to make money but ... to advance the goal of Croatian independence." ${ }^{49}$ Judge Friendly primarily relied upon one textual argument for the Anderson definition. He looked to the use of enterprise in the two preceding subsections of $\S 1962$ that prohibit investing proceeds from racketeering activity in "any enterprise"150 and prohibit the use of a pattern of racketeering activity to acquire "an interest in ... any enterprise."151 He concluded that, "[a]lthough perhaps somewhat wider in its reach than 'business,' an 'enterprise,' as used in these subsections, is evidently an organized profit-seeking venture." 152 There is, of course, a strong presumption that a word has the same meaning in different sections of the same statute. ${ }^{153}$ Thus he concluded that an enterprise under $\S 1962$ (c) must also be the kind of entity in which one could invest proceeds or acquire an interest, neither being a possibility for the terrorist organization.

Only four months after the decision in Ivic, a different panel of the Second Circuit drastically limited it, explaining that Judge Friendly did not really mean that a RICO enterprise need be "an organized profit-seeking venture." Ironically this second decision, United States v. Bagaric, ${ }^{154}$ also involved Croatian terrorists. The significant factual distinction was that the Bagaric organization raised funds for its terrorist objectives by extorting money from wealthy Croatians in the United States. ${ }^{155}$ In language seemingly designed to skirt the issue of whether the organization was an enterprise for RICO purposes, the Bagaric court provided the following strained reading of the Ivic precedent:

States v. Qaoud, 777 F.2d 1105, 1116-17 (6th Cir. 1985), cert. denied, 475 U.S. 1098 (1986); United States v. Clark, 646 F.2d 1259, 1263-67 (8th Cir. 1981); United States v. Altomare, 625 F.2d 5, 7 (4th Cir. 1980); United States v. Grzywacz, 603 F.2d 682, 685-87 (7th Cir. 1979), cert. denied, 446 U.S. 935 (1980).

149. 700 F.2d 51, 60-61 (2d Cir. 1983).

150. 18 U.S.C. § 1962(a) (1988).

151. Id. $\$ 1962(\mathrm{~b})$.

152. 700 F. $2 \mathrm{~d}$ at 60 . The court also referred to the title of RICO, and observed that it would strain ordinary meaning to describe the Croatian terrorist group as "corrupt" or "racketeer influenced." Id. at 61 .

153. Id. at 60. Cunningham's colleague, Kathleen Brickey (an expert on white-collar crime), has pointed out to us that Judge Friendly's textual argument ignores the full text of $\$ 1962$ (a) and (b). Section 1962(a) also prohibits using income received from racketeering activity for "the establishment or operation of, any enterprise." Section 1962(b) also prohibits using a pattern of racketeering activity to "maintain ... control of any enterprise." These broader prohibitions would seem applicable to noncommercial entities.

154. 706 F.2d 42 (2d Cir.), cert. denied, 464 U.S. 840, cert. denied, 464 U.S. 917 (1983).

155. See 706 F.2d at $48-50$. 
The Ivic court nowhere stated, however, that economic gain must be the sole motive of every RICO enterprise. . . . The literal terms of the narrow Ivic holding require no more than an objective appraisal that some economic purpose was to be accomplished by the crime charged .... We recognize that, read in isolation, language in Ivic can be taken to support a requirement that, quite apart from the nature of the predicate acts, the enterprise itself must be "the sort of entity one joins to make money." ... [T] [Tis language is dictum, and differs from the holding of the case, which stated only that because neither the acts charged nor the purpose of the enterprise was economic, the indictment was outside the scope of $\S 1962(\mathrm{c})$. More significantly, the context in which it was employed persuades us the panel had no intention of insisting the necessary showing of economic purpose be confined to the enterprise. . . . The Ivic panel's consideration of the meaning of "enterprise" in subsections (a) and (b) therefore amounted to no more than support for its ultimate conclusion that economic purpose must be shown in either the proof of enterprise or the proof of predicate acts. ${ }^{156}$

The court thus concluded that the RICO indictment was proper because this Croatian organization had a financial purpose for its racketeering activity, specifically, to raise money by extortion. A third case from the Second Circuit, United States v. Ferguson, ${ }^{157}$ followed the lead of Bagaric to uphold a RICO conviction where the alleged enterprise was a black nationalist organization. In Ferguson, the fact that the racketeering activities were bank robberies to support the organization's political activities supplied the "economic element."

Neither Bagaric nor Ferguson came to terms with the impact of their facts on the underlying textual rationale for Ivic. Neither the Bagaric nor Ferguson organizations were entities in which one could invest proceeds or acquire an interest; they certainly were not "organized profit-seeking ventures." Yet if these organizations were not deemed to be enterprises, then the RICO claims fail, regardless of how economically motivated the racketeering activities were.

There exists in the RICO case law another definition of enterprise which can be traced to the Supreme Court's decision in Turkette:

The enterprise is an entity, for present purposes a group of persons associated together for a common purpose of engaging in a course of conduct. ... The "enterprise" is not the "pattern of racketeering activity"; it is an entity separate and apart from the pattern of activity in which it engages. ${ }^{158}$

Under the Turkette definition, PLAN would be an enterprise. Indeed, a women's health center successfully alleged that a more loosely knit pro-life

156. Id. at $53,55,56-57$.

157. 758 F.2d 843 (2d Cir.), cert. denied, 474 U.S. 841 , cert. denied, 474 U.S. 1032 (1985).

158. United States v. Turkette, 452 U.S. 576, 583 (1981). 
organization was a RICO enterprise in a Third Circuit case, Northeast Women's Center, Inc. v. McMonagle. ${ }^{159}$ McMonagle and NOW do not technically represent a split in authority because the RICO defendants in McMonagle did not object to the broader Turkette definition. Indeed, the Turkette definition can be found in many of the same opinions that quote Anderson, as if the two were interchangeable, although Anderson is obviously narrower.

The fact that the Anderson definition is so widely and uncritically accepted, even though the subsequent Second Circuit decisions have shorn away Ivic's textual justification, and even in contexts in which it does not seem applicable to the facts, suggests that the definition reflects some kind of ordinary language intuition. ${ }^{160}$

The linguists designed two empirical projects to explore the ordinary language meaning of enterprise as it might be relevant to the NOW case. Their focus was particularly on the extent to which the Anderson definition of enterprise conformed to ordinary language usage. One project, using surveys data, particularly addressed the "hard cases" for interpreting enterprise: nonbusiness organizations such as labor unions, government agencies, and politically motivated organizations that resemble PLAN or the Bagaric terrorist group. This research, described below, produced the conclusion that, in contrast to the Seventh Circuit's view, enterprise cannot be taken as synonymous with business. To the contrary, while enterprise stereotypically refers to businesses, businesses are actually a subcategory of a larger set of entities that can be described as enterprises in ordinary usage. Moreover, deciding whether PLAN is an enterprise is made unexpectedly difficult because, as indicated by our survey data, English speakers divide into two groups as to how they understand the word enterprise and thus in how they apply the word to a given entity. One way focuses on whether the activity of the enterprise is organized for the achievement of a goal to which the constituent members are jointly committed; the other focuses on whether the entity is like a business. These two ways correspond closely to the "competing" Turkette and Anderson definitions of enterprise.

159. 868 F.2d 1342, 1348 n.5 (3d Cir.), cert. denied, 493 U.S. 901 (1989), cert. denied, 494 U.S. 1050 (1990) (The jury was given the following definition of enterprise: "an ongoing organization, either formal or informal in nature in which the various associates functioned as a continuing unit. The enterprise must have an existence separate and apart from the pattern of activity in which it engages."). This definition actually requires less of a "common purpose" than the definition set forth in Turkette.

160. The Anderson definition may have been given particular credence by its adoption in a set of guidelines promulgated by the U.S. Department of Justice in 1981 to guide prosecutorial discretion in bringing RICO charges. See Ivic, 700 F.2d at 64. The Justice Department has since disavowed this interpretation. Brief for the United States as Amicus Curiae Supporting Petitioners at $17, \mathrm{NOW}, 114 \mathrm{~S}$. Ct. 798 (1994) (No. 92-780). 


\section{Searching the Range of Uses: The NEXIS Database}

In their research on the ordinary meaning of enterprise, the linguists first performed a search of the NEXIS database produced by Mead Data Central for actual documented uses of the word in natural language. The purpose of the NEXIS search was to enlarge the linguists' database beyond whatever examples might have been available by simple introspection. An initial and a second search yielded 192 examples of the word enterprise, from both spoken and written language samples. ${ }^{161}$

When professionally trained linguists review large sets of data in order to study the meaning of a single word, they bring to bear no automatic screening devices or linguistic equivalents of Geiger counters. Rather, they utilize their awareness of grammatical categories, semantic complexities, and other linguistic subtleties. This includes understanding the different ways that a single part of speech, such as a noun or verb, can be used in the grammar of a specific language, the multidimensional nature of word meaning, the role of context in linguistic communication, and the fact that linguistic performance varies among individuals. All of these played a part in the analysis of the NEXIS search product. As explained earlier, ${ }^{162}$ the linguist's skills do not make her more authoritative than any other native speaker, such as a judge, as to whether any particular use of a word is appropriate. The linguist can, however, use the NEXIS search to augment the judge's thinking about possible uses of the word, to suggest distinctions among uses that might escape the judge's notice due to the unconscious nature of language comprehension, and to inform the judge of uses entirely acceptable and current in the relevant speech community, of which the judge might not be aware.

The initial review of the data revealed first that enterprise is used in two grammatically distinct ways: first, as a mass noun, one that normally cannot be pluralized, such as mud or clarity, and second, as a count noun, one denoting an entity we can count, which thus can be pluralized, as in pebbles or qualities. The mass noun category includes the familiar expression, free enterprise. Another mass noun use denotes a personal quality that combines ambition with creativity, as in "[H]ard work and enterprise are also part of the [Vietnamese] culture."163

161. The spoken language samples were from program transcripts of the MacNeil/Lehrer NewsHour and various National Public Radio news broadcasts in 1993. The written language samples were from January 1977 editions of the Washington Post, and October 1989 samples from the New York Times, the Sacramento Bee, the St. Petersburg Times, Time Magazine, and U.S. News and World Report. The actual searching, retrieval, and word processing of these samples to highlight uses of enterprise required only a few hours of time. Levi did most of the following analysis of these examples.

162. See supra text accompanying note 25 .

163. Two other examples of the mass noun use from the NEXIS data are: "[President Ford] said of Latin America only that "our relations have taken on a new maturity and sense of common enterprise,"” and "[T]he small mom-and-pop stores that are the foundation of American enterprise." 
The count noun uses of enterprise are the ones that are relevant to interpreting RICO. In these uses, the noun can appropriately and readily be pluralized, as in these NEXIS citations: "Disney, Universal Studios, and the other tourist enterprises throughout the state" and "What evolved is a mix of academic, scientific, and business enterprises." However, we noted that count noun uses of enterprise can be divided into at least two distinct senses: one which denotes an activity, and one which denotes an entity carrying out such an activity. The first "activity" sense (enterprise ${ }^{a}$ ) is exemplified by these NEXIS citations:

[M]aking and launching that many satellites will be a very expensive enterprise.

[L]iterary history has itself become a far more complex and delicate enterprise than it ever was before.

The second count noun sense, which denotes an entity (enterprise $e^{e}$ ) carrying out one or more activities, is exemplified by these NEXIS citations:

[The National Football League] is a curious enterprise: an intercity alliance of 28 monopolies, blessed by Congress and invariably ruled by fabulously rich capitalists, bound up in its own form of Socialism. [T] he kinship [foster care] program has mushroomed beyond all expectations into a $\$ 200$ million enterprise ....

We concluded that only the enterprise $e^{e}$ sense could be the one intended in RICO. ${ }^{164}$ It is this distinction between enterprise $e^{a}$ and enterprise $e^{e}$ that the RICO defendants were making in arguing that NOW quoted the wrong part, the activity part, of Webster's definition of enterprise. ${ }^{165}$

The data from NEXIS demonstrate conclusively that the count noun enterprise cannot be taken a priori as synonymous with economic enterprise where economic is taken to mean "profit-seeking." There are too many counterexamples in the data to support any such equivalence. ${ }^{166}$ Moreover,

164. This conclusion follows from the fact that the definition of enterprise in RICO, 18 U.S.C. $\$ 1961(4)$, actually mentions specific kinds of entities-including legal ones such as corporations, as well as other groupings of people-but not activities, and thus the statutory definition simply makes no sense in relation to either the mass noun or enterprise uses of enterprise. Similarly, the language of $\$ 1962$ (c) requires that we interpret the enterprise in question as some kind of entity capable of having "activities" and conducting its "affairs." It makes no sense to speak of an activity "the activities of which" do something.

165. See supra text accompanying note 137 .

166. These counter-examples include references to entities in several subcategories such as academic, artistic, educational, joumalistic, political, religious, and scientific. Examples include (with emphasis added):

Sensing its own lure, Princeton University acquired 850 acres from the Rockefeller Medical Institute in 1951 and transformed them into the Forrestal Campus. What has evolved is a mix of academic, scientific and business enterprises.

When we live in a society that tries to ban books like The Adventures of Huckleberry Finn, condemns student enterprises like Not For Profit (an underground high school paper which tried to discuss issues deeper than glorify "the car of the month") and crushes students who try to 
there are eleven occurrences of the expressions business enterprise, commercial enterprise, and economic enterprise. These occurrences, which do not appear to be redundant, also provide evidence for the nonsynonymous relationship of enterprise and economic enterprise, as opposed to the apparent redundancy of commercial business or economic business.

Another conclusion we reached from reviewing the NEXIS data is that "organized profit-seeking entities," entities which may be roughly characterized as equivalent to what is meant by the term businesses, represent the largest share of the entities referred to as enterprises. We further observed that a small number of citations, not counting those that used enterprise in the context of a RICO prosecution, showed enterprise as denoting criminal organizations or criminal activities, thus demonstrating that use of the word is not restricted to entities and organizations that conform to the law. ${ }^{167}$

Our final conclusion concerning the NEXIS data was that, as far as we could tell from the contexts provided in the fifty-word quotations, for all examples of enterprise, the enterprise could be characterized as having a goal of some sort, although not necessarily the goal of seeking profits. This common feature turned out to be very significant in the responses of the subjects to a survey designed to expand the database on the ordinary use of enterprise one step further.

\section{Looking to the Speech Community: Investigating Native Speaker Judgments via Questionnaires}

Based on the NEXIS data and previous work on descriptive lexical semantics, ${ }^{168}$ we then designed a survey questionnaire. We designed the survey in part to test the Anderson definition of enterprise used by the Seventh Circuit in NOW: "an association (1) having an ascertainable structure (2) which exists for the purpose of maintaining operations (3) directed toward an economic goal (4) that has an existence that can be defined apart from the

tackle the pressing issues of the day ....

[In Iraq] a monstrous political order has taken hold, an order that has grafted modern methods of totalitarian control into an old form of Middle Eastern despotism. At the core of this enterprise is the cult of the ruler, Saddam Hussein: the ruler as master, all-knowing, all-seeing.

For further examples of this usage of enterprise, see infra Appendix B.

167. Examples include (with emphasis added):

The National Security Council has launched an investigation to identify who is behind the smuggling enterprise, which is now a $\$ 3$ billion-a-year industry.

So far, the [New Haven] task force claims credit for destroying one gang, uncovering a major criminal enterprise, and bringing peace to one New Haven neighborhood.

Schultz and three henchmen ... had spent the evening at a table in the back room going over their receipts from their enterprises.

Another concern of American officials is that the traffickers might reach an accommodation in Colombia and shift their cocaine enterprises to other South American countries.

168. Kaplan did the initial survey design and most of the analysis of survey results that appears below. Kaplan's main source for the type of survey he designed was Linda Coleman \& Paul Kay, Prototype Semantics: The English Word Lie, 57 LANGUAGE 26 (1981). 
commission of the predicate acts constituting the pattern of racketeering activity."169 The survey asked subjects whether certain real or hypothetical groups were enterprises, and contained examples written to test whether entities similar to PLAN and the Croatian terrorist group in Bagaric would be considered enterprises. It also asked if a well-known labor union, the United Auto Workers, and a well-known government agency engaged in economic activity, the Internal Revenue Service, were enterprises.

\section{a. Methodology}

The following survey question illustrates the format used for each question:

The IBM (International Business Machines) Corporation.

(a) Does it seem right, to you, to call the International Business Machines (IBM) an "enterprise?"

(b) I am

YES I CAN'T TELL NO

VERY SURE FAIRLY SURE NOT TOO SURE that most others would agree with the choice I circled in response to question (a).

We scored their combined answers on a scale from 1 to 7 as follows:

NO CAN'T TELL YES

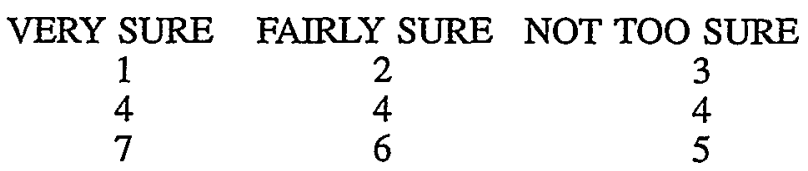

After several pre-tests by Kaplan at San Diego State University and by Cunningham at Washington University, ${ }^{170}$ we developed a final set of twelve questions. To keep the time for survey completion short, the twelve questions were split between two different questionnaire forms so that, in any given survey session, half the group was answering the six questions on Survey A and the other half the six questions on Survey B. ${ }^{171}$ The survey was administered three times, to students at Northwestern University, Washington

169. National Org. for Women, Inc. v. Scheidler, 968 F.2d 612, 627 (7th Cir. 1992), cert. granted, 113 S. Ct. 2958 (1993), rev'd, 114 S. Ct. 798 (1994) (quoting United States v. Anderson, 626 F.2d 1358, 1372 (8th Cir. 1980) (emphasis added by the NOW court, numbers inserted by author)).

170. The authors received considerable assistance during the pre-test period from Lee Robins, University Professor of Social Science at Washington University, who has very extensive experience in survey research.

171. The items which appeared on the surveys are presented in full in Appendix $C$. In addition to six questions regarding enterprise, each survey also contained three questions relating to the word exhibit as part of our research on the Knox case. See supra note 2. 
University, and San Diego State University. ${ }^{172}$ In total, there were fifty-four respondents to Survey $\mathrm{A}$ and sixty-two to Survey $\mathrm{B}$. The surveys given to respondents in two of the sample groups also asked them to explain briefly "Why or Why Not" after circling "Yes," "No," or "Can't Tell," and before choosing among the "Very Sure," "Fairly Sure," and "Not Too Sure" options. We subsequently mailed to 127 U.S. District Court judges a survey that contained six examples from Surveys $\mathrm{A}$ and $\mathrm{B}$, including those most relevant to $\mathrm{RICO} ;{ }^{173} 37$ judges responded. As will be shown in more detail below, their responses corresponded with those of the college students, in particular as to the most important examples, and thus provide convergent evidence supporting the model of the speech community's range of uses of enterprise derived from the original survey's responses. ${ }^{174}$

In using surveys to explore further the meanings of enterprise, the authors are not suggesting that judges should delegate to others the task of ascertaining just how statutory terms should be applied to particular cases. Nor do we suggest that legal meaning is something that can be determined by an opinion poll. ${ }^{175}$ Rather, as with the NEXIS data, the surveys are a device for expanding an individual's ability to bring to conscious awareness her intuitive understanding of word meaning, and for informing an individual of perfectly

172. At San Diego, the subjects were students in a linguistics class taught by Kaplan; at Northwestern the subjects were students in a linguistics class taught by Levi. The Washington University subjects were students in an undergraduate course in social methods taught by Lee Robins, see supra note 170; Cunningham was present when the survey was administered. None of the subjects were given any information or instructions beyond what appeared on the survey questionnaire itself. Washington University students received Survey A and B in four different forms with question sequencing randomized on Robins' advice; the randomizing did not seem to affect responses.

173. The survey was mailed to all active and senior status federal district court judges in Alabama, Idaho, Illinois, Michigan, Missouri, New Hampshire, and New Mexico. The selection of states represented a rough balance among regions of the country and between urban versus rural districts. Because the survey was mailed from Washington University and the cover letter identified linguistics professors at Northwestern University and the University of Illinois as part of the team designing the survey, it was hoped that judges in Missouri and Illinois would be particularly likely to respond. Although the cover letter to the judges did state that "the Supreme Court will hear argument on cases that require interpretation of these words [enterprise and exhibit] in two federal statutes," no explicit reference to RICO or the NOW case was made. Further, the judges were asked "not to answer any question based on your belief of what the word should mean in any particular federal statute or how it should be interpreted in any pending case." Letter to Federal Judges Re: Statutory Interpretation Project (Oct. 27, 1993) (on file with Prof. Clark Cunningham).

174. These judges were surveyed for two reasons. First, they are representative of one group that must interpret RICO on a case by case basis, and must apply whatever definition the Court develops in deciding the NOW case. Second, even though this project was not aimed at determining legislative intent, the authors anticipated possible criticism that the college student respondents, although literate and thoughtful, might be too divergent in age and life experience from the people who enacted RICO to be relevant. The district court judges seemed to be a group that would be motivated to respond to the survey and who would more closely approximate the age and life experience of the legislators who voted on RICO, assuming that is a relevant factor. The authors also sent the same survey received by the judges to 146 current members of Congress, targeting the members with the longest terms of service. Only five returned completed surveys; six wrote letters explaining they have a policy of not answering surveys.

175. Judges should, however, take survey data very seriously in regard to whether a word or phrase is ambiguous as a matter of ordinary language. It is very hard to maintain that a particular utterance is capable of only one interpretation if large numbers of native speakers can be shown to disagree about its interpretation. 
acceptable and normal uses, or subtleties thereof, that a word may have in the speech community - uses of which the individual might not previously have been aware.

\section{b. Results and Discussion}

Tables A and B contain the average score and the standard deviation for each response across the three groups of student subjects, along with a measure (a two-tailed t-test) of whether the average score for each item is significantly lower than the score of the item listed just above it. Table $C$ displays the results from the judges.

Of particular interest for present purposes is the fact that the example designed to track closely the features of the Pro-Life Action Network (PLAN) as described in the NOW case ${ }^{176}$ was the example that scored most like an enterprise after IBM and the Small Company. This example was in a statistical tie for first place with three other entries in the judges' survey. ${ }^{177}$ The survey described the PLAN-type example as follows:

The Coalition for Fair Adoption Laws (CFAL) is a highly organized national network of non-profit organizations representing adoptive parents and persons seeking to adopt. The executive directors of the member organizations comprise the steering committee of CFAL. CFAL's activities include lobbying, rallies, and planning demonstrations at courts and adoption agencies.

176. PLAN is a highly organized nationwide network of anti-abortion activists; its "steering committee" is comprised of the executive directors of several member organizations. PLAN is responsible for the overall national strategy of national conferences and training sessions, promotion of national agendas, and direct action against abortion clinics. Brief of Petitioners at 7, NOW, $114 \mathrm{~S}$. Ct. 798 (1994) (No. 92-780). PLAN raises funds which support staff salaries, office expenses, and other operational costs. Id. at 47.

177. The judges' survey did not include either the IBM or Small Company questions. See infra Appendix C. 
TABle A. Survey A (54 University Students)

\begin{tabular}{|l|l|l|l||}
\hline $\begin{array}{l}\text { Question } \\
\text { (1:No/Very Sure to } \\
\text { 7:Yes/Very Sure) }\end{array}$ & $\begin{array}{l}\text { Average } \\
\text { Score }\end{array}$ & $\begin{array}{l}\text { Standard } \\
\text { Deviation }\end{array}$ & $\begin{array}{l}\text { Difference } \\
\text { Statistically } \\
\text { Significant at .01 } \\
\text { Level? } \\
\text { (By 2-tailed t-test) }\end{array}$ \\
\hline \hline Small Company & 6.42 & 1.05 & \\
$\begin{array}{l}\text { Coalition for Fair Adoption } \\
\text { Laws (CFAL) }\end{array}$ & 4.7 & 1.89 & \} Yes (P=.0000) \\
$\begin{array}{l}\text { Independent Quebec } \\
\text { Organization (IQO) }\end{array}$ & 3.96 & 1.93 & \} Yes (P=.0007) \\
Internal Revenue Service \\
(IRS)
\end{tabular}

* Difference Significant at .05 Level 
TABlE B. Survey B (62 University Students)

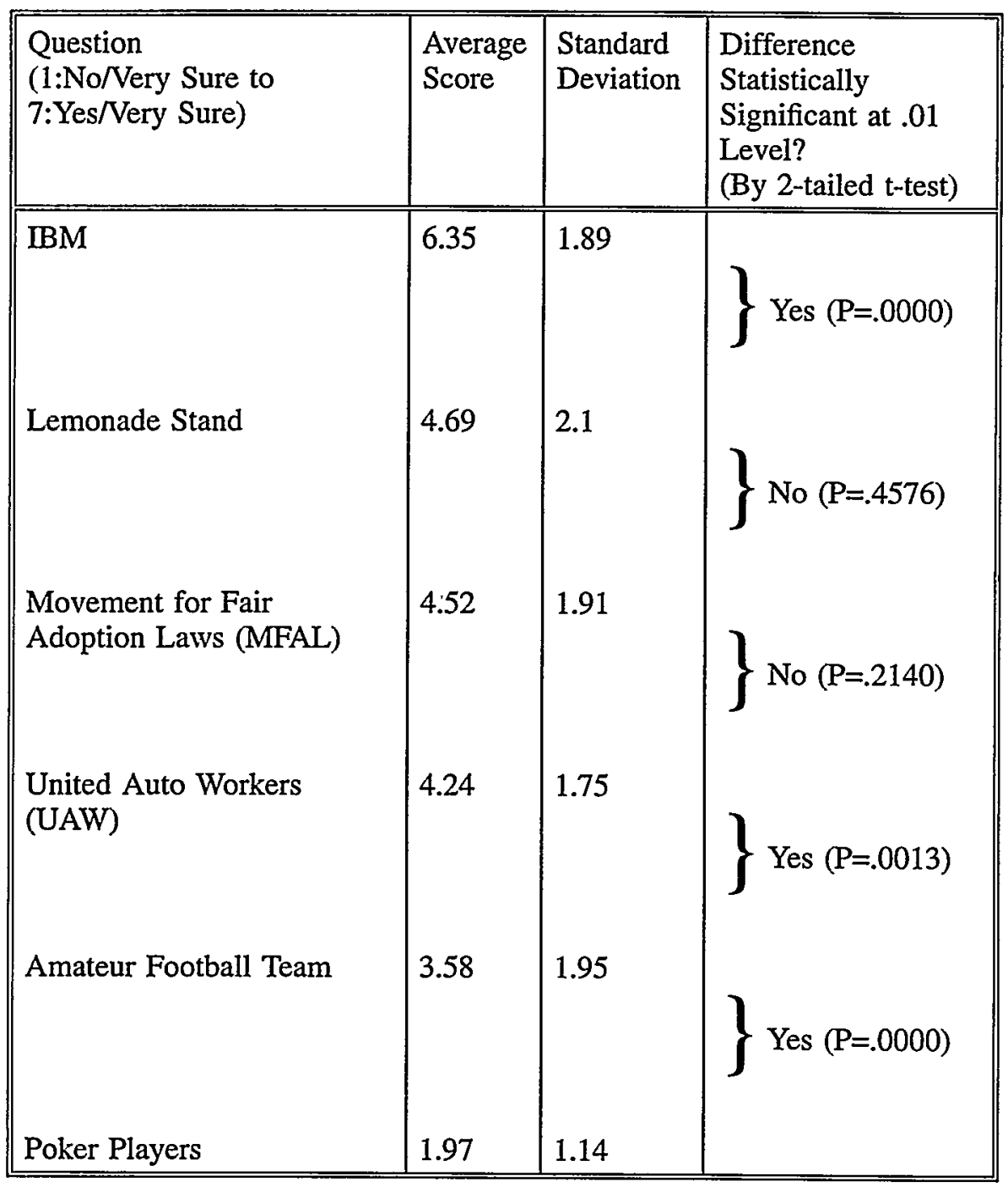


TABLE C. Survey C (37 District Court Judges)

\begin{tabular}{|c|c|c|c|}
\hline $\begin{array}{l}\text { Question } \\
\text { (1:No/Very Sure to } \\
\text { 7:Yes/Very Sure) }\end{array}$ & $\begin{array}{l}\text { Average } \\
\text { Score }\end{array}$ & $\begin{array}{l}\text { Standard } \\
\text { Deviation }\end{array}$ & $\begin{array}{l}\text { Difference } \\
\text { Statistically } \\
\text { Significant at .01 } \\
\text { Level? } \\
\text { (By 2-tailed t-test) }\end{array}$ \\
\hline $\begin{array}{l}\text { Independent Quebec } \\
\text { Organization (IQO) }\end{array}$ & 5.32 & 2.01 & No $(\mathrm{P}=.2980)$ \\
\hline $\begin{array}{l}\text { Coalition for Fair Adoption } \\
\text { Laws (CFAL) }\end{array}$ & 4.8 & 1.81 & \} No $(P=.7260)$ \\
\hline Lemonade Stand & 4.66 & 2.1 & No $(\mathrm{P}=.7810)$ \\
\hline $\begin{array}{l}\text { United Auto Workers } \\
\text { (UAW) }\end{array}$ & 4.46 & 2.01 & \} Yes $(P=.0000)$ \\
\hline $\begin{array}{l}\text { Internal Revenue Service } \\
\text { (IRS) }\end{array}$ & 2.4 & 1.46 & \}$_{\text {No }}(\mathrm{P}=.1050)$ \\
\hline Bible Study Group & 1.97 & 1.04 & \\
\hline
\end{tabular}


The CFAL results were notable not only for the high scores but also for the distribution of answers. Specifically, $70 \%$ of the student respondents and $66 \%$ of the judges were either very sure or fairly sure that others would agree with their judgment about whether CFAL was or was not an enterprise. ${ }^{178}$ The average scores of 4.7 for students and 4.8 for judges are thus primarily the result of offsetting high and low scores, ${ }^{179}$ rather than a high number of "I Can't Tell" responses. Graphs 1 and 2 most accurately display this distribution.

Also of particular interest for RICO purposes was the scoring of the Independent Quebec Organization (IQO), an entity designed to track the features of the Croatian terrorist group that the Second Circuit found to be an enterprise in Bagaric: "The Independent Quebec Organization is a terrorist group that robs banks and extorts money from wealthy, French-speaking Canadians to finance its bombing, arson, and assassination activities." The students rated IQO significantly lower than CFAL, but the judges rated IQO relatively high. ${ }^{180}$ Graphs 3 and 4 show the distribution of scores for this item.

178. From this point forward, we will refer to respondents "being sure" about a particular judgment rather than fully stating that they were sure that others would agree. We adopted the seven point scale from the Coleman and Kay experiment mentioned above. Coleman \& Kay, supra note 168. Coleman and Kay actually sought to discover the respondent's strength of conviction in her own judgment but found in a pretest that subjects seemed to circle "I am very sure" despite other indicators, such as long hesitation and facial gestures during testing, that seemed to indicate uncertainty. Id. at 30 . Thus they reformulated the "sure" question to ask about whether others would agree in order to investigate indirectly the subject's own certainty. For our purposes, certainty that others would agree with the subject's own judgment is if anything a more significant indicator of speech community usage than the speaker's personal conviction of certainty.

179. Among the students, $50 \%$ were either very sure or fairly sure that CFAL was an enterprise, while $20 \%$ were either very sure or fairly sure it was not. Among the judges, $54 \%$ were either very sure or fairly sure that it was an enterprise, $11.5 \%$ were very sure or fairly sure it was not.

180. For the judges' survey, the differences between the average score for IQO and the average scores for CFAL, UAW, and Lemonade Stand were not statistically significant according to the two-tailed t-test, as indicated by the "p value" column in Table C. Nonetheless, the authors are intrigued by the difference in distribution of scores for IQO between the students and the judges as displayed in graphs 3 and 4 . Eight subjects in the San Diego State and Washington University surveys (the two groups asked to explain "Why or Why Not" they answered as they did) provided explanations for answering "No" as to IQO. Six out of these eight explained that IQO is "not legal" or engages in "negative activities." We speculate that the judges (who were not asked in their survey to provide explanations) were accustomed to the concept of a "criminal enterprise," and thus were not dissuaded to the same degree by the illegal nature of IQO's activities. In the same vein, it is possible that some of the judges were familiar with the Bagaric precedent, and thus readily identified IQO as a RICO enterprise, despite the instructions not to interpret enterprise for purposes of any particular statute. 
GRAPH 1. Coalition for Fair Adoption Laws

(Student Respondents)

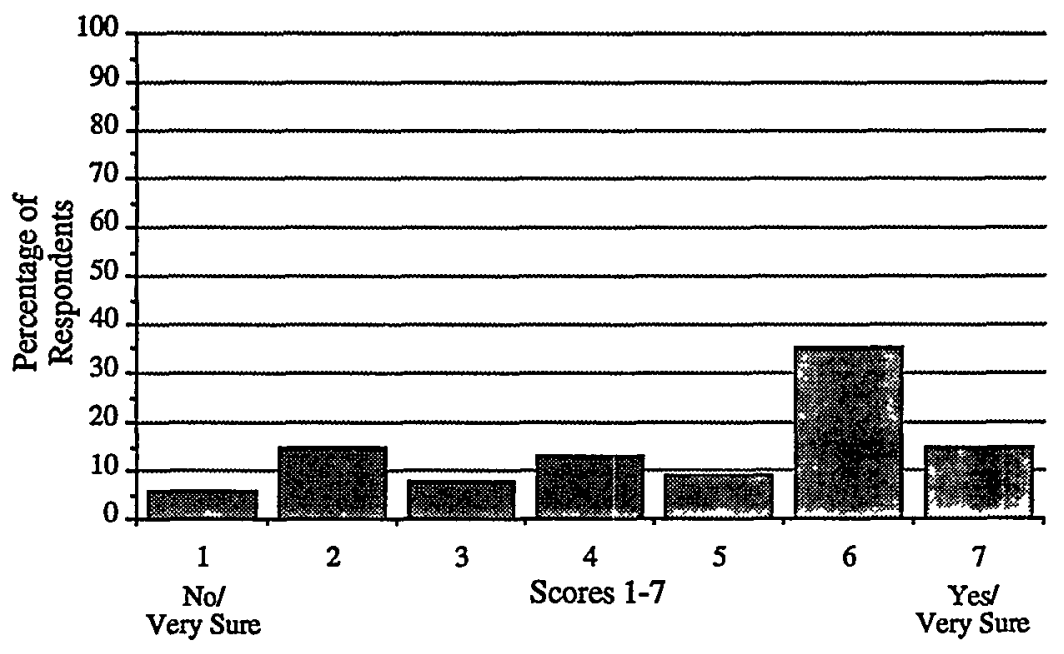

GRAPH 2. Coalition for Fair Adoption Laws

(Judge Respondents)

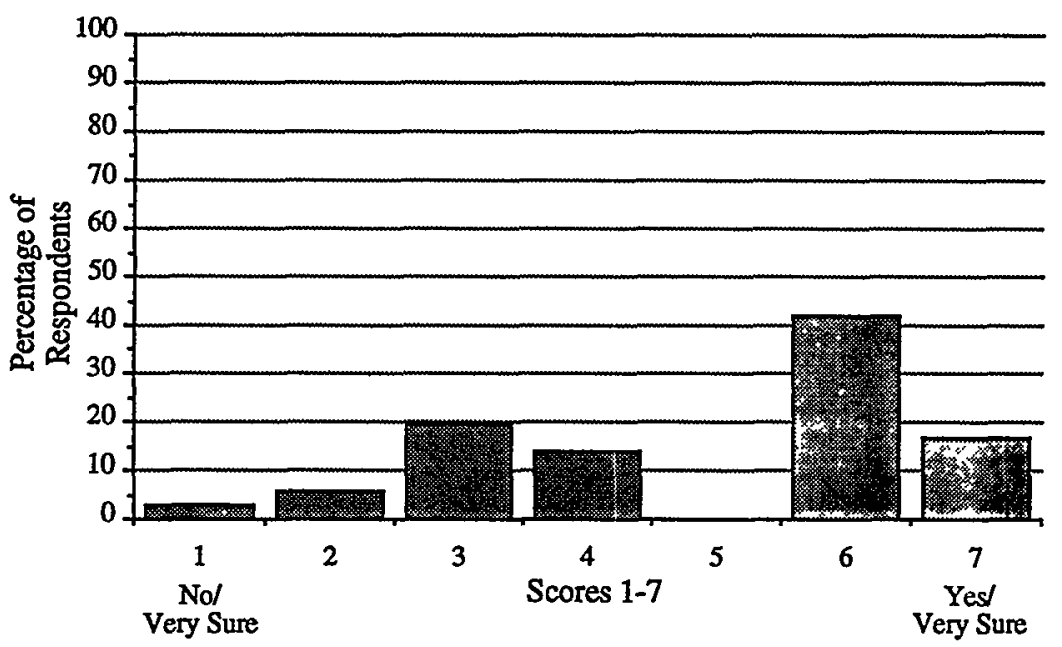


GRAPH 3. Independent Quebec Organization

(Student Respondents)

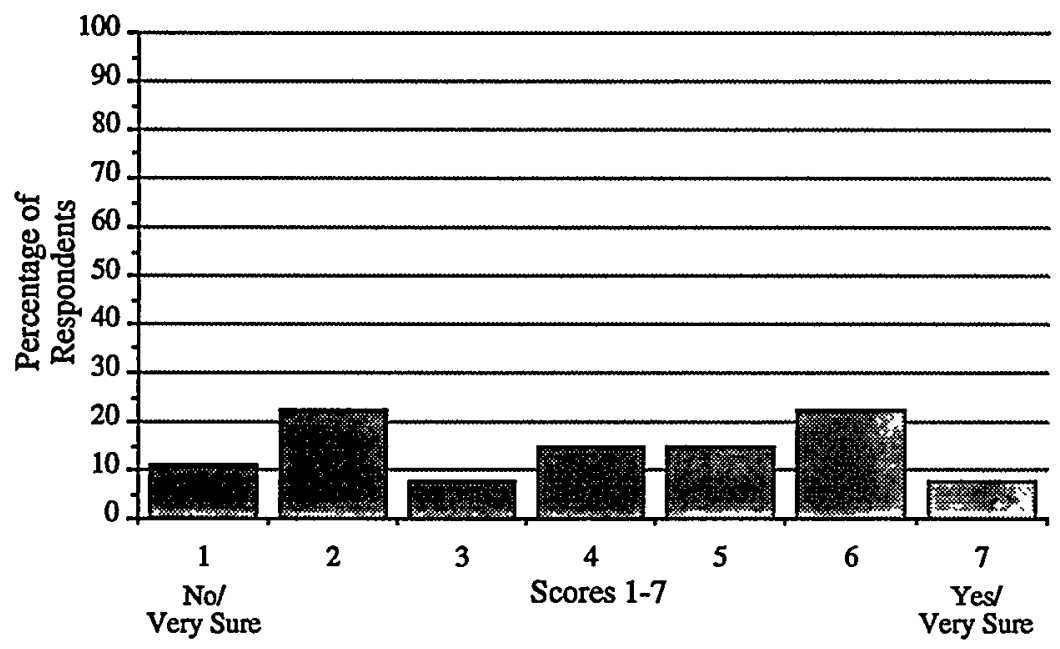

GRAPH 4. Independent Quebec Organization

(Judge Respondents)

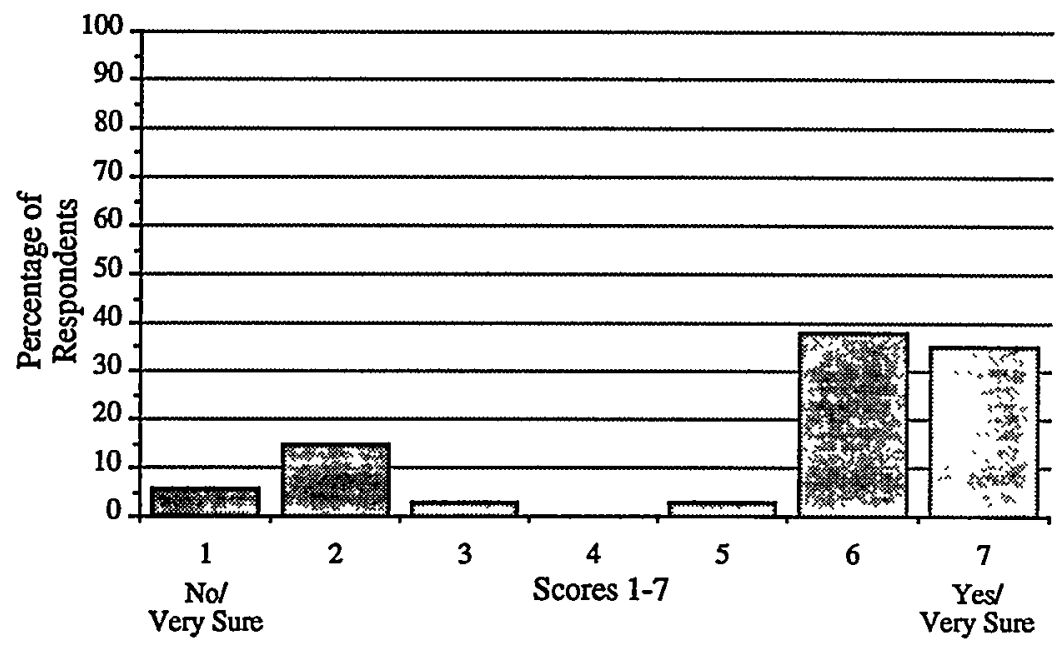


A highly structured legal organization devoted to raising money, the Internal Revenue Service, rated low for both students and judges. Twice as many student respondents said "No" with at least fair certainty than said "Yes." Even more strikingly, 70\% of the judges said "No" with at least fair certainty as contrasted with only $6 \%$ saying "Yes" with such certainty.

On the basis of these results, it can be concluded that the Anderson definition used by the Seventh Circuit to dismiss NOW's RICO claim does not correspond well with the way most speakers understand enterprise, since an overwhelming majority of both the students and judges responding thought that at least one entity was an enterprise that lacked at least one of the elements of that definition: economic goal, ascertainable structure, and independent existence. CFAL received an average rating of 4.7 from the students and 4.8 from the judges, despite having no economic goal, about the same as Lemonade Stand which rated 4.69 from the students and 4.66 from the judges. Lemonade Stand does have an economic goal but has minimal structure and no existence independent of the momentary activity. ${ }^{181}$ Moreover, the implicit fund-raising activities of the IRS were not sufficient to earn it an average rating close to that of CFAL. ${ }^{182}$ Indeed, nothing in the Anderson definition of enterprise can explain why such a highly structured and independently existing entity as the IRS was rated so much lower than CFAL.

Respondents' answers to the Why/Why Not questions helped to explain the striking results. The subjects divided into two distinct, albeit related, groups in regard to the primary criterion for categorizing an entity as an enterprise. The first group centered on the entity's having a clear goal, while the second group focused on one very specific goal, seeking a profit. ${ }^{183}$

The subjects' explanations of why they rated CFAL as they did demonstrate this bifurcated pattern. Of the twelve respondents who provided Why/Why Not answers and felt that CFAL was an enterprise, all but two mentioned the organization having a goal. ${ }^{184}$ In sharp contrast, all five of the

181. The Lemonade Stand was described simply as "Three children selling lemonade on a street corner." See infra Appendix C.

182. The IRS received an average rating of 3.96 from the students and only 2.4 from the judges.

183. The split between these two approaches can be seen in several ways in the Why/Why Not responses. A tally of all the properties of enterprise that subjects mentioned shows that $65 \%$ mentioned "seeking a profit" and 54\% mentioned "having a goal." In this count, the number mentioning the latter does not include subjects mentioning the former, although seeking a profit is a kind of goal. Other properties were mentioned by far fewer subjects. For example, $25.5 \%$ mentioned "having group unity," $22 \%^{\circ}$ mentioned "having official status," and only $16 \%$ mentioned "having structure." Moreover, only $4 \%$ of the subjects who provided Why/Why Not responses failed to mention either "seeking a profit" or "having a goal"; $41 \%$ mentioned profit but not goal, $31 \%$ mentioned goal but not profit, and $24 \%$ mentioned both. For further discussion of these responses, see infra Appendix $\mathrm{E}$.

184. The two who did not mention goal said: "Maybe not because is non-profit group" and "They are all working together." The former comment was apparently an explanation of why the subject was "Not Too Sure" others would agree with his answer rather than of why the subject thought CFAL was an enterprise. The latter explanation could arguably be understood as implying a goal. 
"No" respondents who disagreed and explained why CFAL was not an enterprise mentioned CFAL's lack of an economic goal.

As one might have expected, respondents' explanations for their ratings of the Movement for Fair Adoption Laws (MFAL), an entity designed to be similar to CFAL but less structured, ${ }^{185}$ show the same pattern as seen in the CFAL responses, namely the contrast between "having a goal" and "seeking a profit" as the primary criterion. ${ }^{186}$ One "Can't Tell" respondent explicitly stated the clear tension between "goal" and "profit-seeking": "It's very possible that having a large group of people working together for a common purpose is an enterprise, but I tend to think that enterprises make money."

An examination of the explanations for the UAW, the IRS, and the IQO shows that the "goal" versus "profit-seeking" dichotomy drives those responses as well, but with a difference that strongly suggests why CFAL and MFAL produced fewer "Can't Tell" and more "sure" responses in both directions. CFAL and MFAL had very clearly identified goals that defined the organizations, and they were also clearly not motivated by making money. As a result, respondents who weighed the "goal" feature heavily felt sure that they were enterprises, and those who thought an enterprise needed to be profitseeking were sure that they were not. The relative few who marked "Can't Tell" seemed to feel an equal pull from both features and were thus immobilized by the sharp choice that CFAL and MFAL offered between them. In contrast, the relatively strong showing for UAW shows about half the affirmative votes coming from those who weigh goal-orientation heavily and thought the UAW has a clear goal, and the rest from people who thought the UAW makes money or is otherwise like a business. The "Yes" responses to IQO show the same pattern. The IRS, in contrast, rated much lower because very few of the "goal" weighing respondents thought it had a clear goal; the relatively few "Yes" explanations ${ }^{187}$ emphasized its money-raising function.

In brief, among those respondents who expressed a reason for answering any of the questions, there was almost total correlation between whether the respondent preferred a "goal" or "profit-seeking" explanation and how the respondent decided the "hard" cases.

It is possible to contrast the "profit-seeking" and "goal" ways of understanding enterprise by considering two different ways that people might

185. MFAL was described as "an unstructured network of political activists, who favor freer adoption. With much intercommunication among 'members,' MFAL's activities consist of, among other things, planning demonstrations at courts and adoption agencies." See infra Appendix C.

186. Of the fourteen respondents who indicated that MFAL was an enterprise and explained their answer, eleven referred to MFAL's having a goal. Of the six respondents who said MFAL was not an enterprise and explained why, two mentioned that it lacked a profit-making focus, two mentioned that it lacked structure, and two gave essentially "empty" explanations. Those two explanations were: (I) "Think of enterprise as something else" and (2) "I have only heard the word "enterprise' to describe inanimate things."

187. Almost no one was "very sure" that the IRS was an enterprise. 
decide whether to apply the familiar word enterprise to an unfamiliar entity such as the (hypothetical) Coalition for Fair Adoption Laws. One way is to think about enterprise-as-entity, and then compare CFAL to the stereotypical enterprise-as-entity, namely a business. This way could produce the kind of rankings given by the "seeking a profit" group. The "have a goal" group could have proceeded differently, by focusing on enterprise-as-activity, even though the examples were all entities.

The two conceptions of an enterprise as a goal-directed activity and as a goal-directed entity correspond to a more general relation between an activity and concrete manifestations of that activity, as Green has discussed in detail elsewhere. ${ }^{188}$ Thus English speakers use and understand constitution as either a process of constituting or a written charter that constitutes a nation or organization, and shelter as the state of being sheltered, as in "Shelter is a basic human need," or as a structure that enables that state, as in "Shelter is expensive." 189 This process may be at work for those who used the "goal" way of understanding enterprise: the respondent relates the novel entity to the activity in which it apparently engages, and then compares that activity to familiar enterprise activities, which generally have clear goals, though not necessarily profit-seeking goals.

The survey work generates several conclusions. First, disagreement among members of the same speech community, for both the students and the judges, over whether a given entity is an enterprise is not entirely attributable to what Solan terms "categorical indeterminacy" or "fuzzy words." Rather for some examples, most notably CFAL, most speakers who disagree about whether the example is an enterprise agree that the issue is not "fuzzy." They feel sure that most others would agree with their own conclusion about membership in the category. The relatively few "Can't Tell" responses for such examples further suggest that the interpretive challenge is not a problem of marginal membership in a category. ${ }^{190}$

Second, this disagreement is not a result of speakers choosing between two meanings which all speakers use, as is the case of homonym pairs like bank as the land edge next to a river and bank as a financial institution. Rather, speakers differ in how they apply enterprise to entities. One group looks at whether an entity has a clear goal; the other asks whether the entity is like a business.

Third, for the many who use "having a goal" as their primary criterion, the word enterprise may denote both "economic," profit-seeking enterprises and

188. See, e.g., GREEN, PRAGMATICS, supra note 6, at 47-61.

189. Another example of a relation between a state of affairs and the entities whose properties constitute it is seen in the following two sentences: "Snow is forecast for tomorrow," and "Snow is cold." The word snow is used quite unremarkably to refer to either a process or the concrete manifestation of that process.

190. See supra text accompanying note 108 . 
noneconomic enterprises. For this substantial part of the speech community, whether a nonbusiness entity is an enterprise does not turn on the degree to which the goal is economic. Rather, for such persons, the clarity of its goal and the extent to which the entity is identified with that goal is more salient.

Fourth, it is only for that part of the speech community which uses "profitseeking" as the primary criterion that the economic character of the entity's goal is salient. However, even for this group, the other features of the Anderson definition-ascertainable structure and independent existence-do not state necessary conditions for being an enterprise, as demonstrated by the number who are sure that Lemonade Stand is an enterprise.

Fifth, because of these conclusions, reasonable members of the speech community can and do differ as to whether they consider a goal-oriented but non-profit-seeking entity such as PLAN to be an enterprise.

Sixth, businesses are the stereotypical enterprises for both groups. However, this does not mean that business and enterprise are synonymous, any more than the fact that Americans consider a robin to be a stereotypical bird means they believe that the word robin is a synonym of bird.

These results, along with those from the NEXIS search, give rise to the following implications for the NOW case. Many if not most speakers would consider describing PLAN as an enterprise to be an appropriate use of the word, although some speakers would disagree with certainty. People who identify an enterprise primarily by its clear goals would classify PLAN as an enterprise, because it has a clear and specific goal; the activities it generates to accomplish that goal readily meet their understanding of enterprising activities; ${ }^{191}$ and it is an organizational embodiment of its goal-directed activity. For these persons, PLAN's clear commitment to a specific goal is likely to make it seem as much or more like an enterprise as entities like terrorist groups, labor unions, and government agencies.

On the other hand, for people who apply an economic criterion in deciding whether an entity is an enterprise, PLAN will probably not qualify because its economic activities are so incidental to its organizational goals that it does not significantly resemble a profit-seeking business. However, such people may also conclude that terrorist groups, labor unions, and government agencies are not enterprises because they too do not seem enough like businesses.

Both groups appear to treat "having a goal" as essential, though they differ in whether that goal must be an economic one. In fact, the two ways of interpreting enterprise that have emerged from our empirical research correspond closely to the "competing" Turkette and Anderson definitions of enterprise. Thus the circuit splits appear to reflect actual features of ordinary language usage, which may do much to explain the origin and persistence of both definitions, including the unreflective way courts use each in the case law.

191. See supra p. 1597. 
The larger statutory context in which enterprise appears in RICO seems to point in both directions. As recognized in Ivic, the "business-like" or "economic goal" criterion seems relevant to the first two of RICO's three prohibitions: § 1962(a) prohibits investment in an enterprise and $\S 1962(\mathrm{~b})$ prohibits acquiring an interest in an enterprise. ${ }^{192}$ On the other hand, a fair interpretation of the statute's definitional subsection on enterprise, with its "includes" phrasing, is that Congress intended to expand the meaning of enterprise in RICO beyond businesses. ${ }^{193}$ In particular there is little doubt that Congress intended to protect labor unions from racketeering influence and corruption; textual evidence to that effect in both the mention of unions in the definition of enterprise ${ }^{194}$ and the inclusion of labor unions in conjunction with businesses in the preamble to the Act. ${ }^{195}$ Yet, at least according to our survey data, the "business-like" criterion does not readily lead to the conclusion that unions such as the UAW are enterprises. ${ }^{196}$

The lessons from the linguists' analysis and the tangled case law seem to merge. Some speakers, thinking of a business as the stereotypical enterprise, will apply the word to entities whose primary goal is profit. However, such a meaning of enterprise excludes a wide range of entities regularly, and according to many speakers properly, called enterprises. Inclusion of this wider range of entities entails replacing the narrow "business-like" criterion with a broader criterion that focuses on whether the entity is dedicated to a clear, specific goal. Courts attempting to retain the narrow focus on economic goal while at the same time including nonbusiness organizations such as PLAN, terrorist groups, labor unions, or government agencies within the definition of enterprise run counter to the ordinary language patterns of usage and are likely to generate incoherent discourse.

The linguistic analysis we have presented of course is not offered as a "right answer" to how the NOW case should be decided. The role of linguists has been to analyze the language, not to make judicial decisions about the legal implications of such analysis. Rather the analysis has shown that both the Anderson and Turkette definitions have roots in ordinary language. Further, there can be a host of sound legal reasons why enterprise should have a different meaning in RICO than in ordinary language. Nevertheless, the analysis by linguists could help judges articulate their own intuitions about how the word enterprise is ordinarily used, and at the same time show judges what the range of uses of this word appears to be in the speech community.

192. See supra notes $149-52$ and accompanying text. However, as discussed in note 153 , Ivic may be reading $\$ 1962$ (a) and (b) too narrowly as applying only to business-like entities.

193. See supra notes 131-34 and accompanying text.

194. 18 U.S.C. \$ 1961(4) (1988).

195. Pub. L. No. $91-452,84$ Stat. 922 (1970).

196. Consider the following Why/Why Not explanations from respondents who said the UAW is not an enterprise: "they're workers, not a business," "this group does not seek financial gain," "not making money primarily," and "they don't work together or cooperate to make money for themselves." 
Both of these contributions could help a judge understand how other judges might come to different conclusions about what this word "plainly means." The discourse between those disagreeing judges could then rise above mere unarticulated assertion of personal understanding or invocation of a strategically chosen dictionary edition. Instead it could become informed by such objectively derived distinctions as those between activities and entities and between the "goal" and "profit-seeking" criteria for deciding whether a nonbusiness organization is an enterprise.

To the extent that a court's opinion explicitly selected one of these two criteria, subsequent applications of that opinion to new cases might be more coherent and predictable because the actual rationale would be seen clearly, and the unjustified claims that "ordinary language" simply dictates a single result would not be present. However, even if the language of RICO is not so plain as to dictate a single result, its language can still guide judicial decisionmaking: for even in a case that apparently presented what Solan views as an intractable problem of fuzzy category boundaries, analysis of ordinary language meaning does provide a degree of determinacy through identifying and articulating these two distinct criteria. In this way, an empirical study by trained language analysts can help untangle the linguistic knots that led to NOW becoming a "hard" case. ${ }^{197}$

197. On January 24,1994 , less than seven weeks after oral argument, the Court issued a unanimous decision in favor of NOW; Chief Justice Rehnquist authored the brief opinion. $114 \mathrm{~S}$. Ct. 798, 798-806 (1994). Justice Souter wrote a one page concurrence, joined by Justice Kennedy, emphasizing that the decision did not address whether the abortion protesters might have some First Amendment defense to a RICO suit. Id. at 806-07.

The Court's quick unanimous decision and its terse opinion refuted expectations that the highly politicized nature of the underlying abortion protest issue, an element which made the case one of the most publicized of the term to date, would produce a lengthy and splintered set of opinions. The NOW case makes a striking contrast with last term's decision in Bray v. Alexandria Women's Health Clinic, $113 \mathrm{~S}$. Ct. 753 (1993) (the "Operation Rescue" case), also brought by NOW and abortion clinics against antiabortion protesters, but under the anticonspiracy provision of the Civil Rights Act of 1871,42 U.S.C. $\$$ 1985 (3). Justice Scalia's majority opinion in Bray, holding that NOW did not have a cause of action, was one of five opinions produced by the fractured Court-all totalling 49 pages in the Supreme Court Reporter.

The content of the NOW opinion itself, along with the swiftness, unanimity, and brevity of the decision, indicate that the Justices' reliance on their own linguistic intuitions about the "plain meaning" of enterprise may have been a most significant factor. The key to Rehnquist's opinion appears to be the presupposition that enterprise as used in ordinary language is appropriately applied to PLAN. This presupposition is apparent in statements that begin and end the substantive discussion in the opinion: "We turn to the question of whether the racketeering enterprise or the racketeering predicate acts must be accompanied by an underlying economic motive," 114 S. Ct. at 803 (emphasis added), and "the question presented for review asked simply whether the Court should create an unwritten requirement limiting RICO to cases where either the enterprise or racketeering activity has an overriding economic motive." Id. at 806 n.6 (emphasis added). Rehnquist is able to agree with NOW's characterization of the economic motive requirement as "unwritten" because he takes as self-evident that the meaning of enterprise does not contain such a requirement. His opinion focuses instead on whether the text of RICO contains other evidence of an economic motive requirement. Rehnquist finds only two provisions deserving of attention. The first is the requirement in $\$ 1962$ (c), the provision that NOW accused the abortion protestors of violating, that the enterprise "affect commerce." See supra note 124 and accompanying text. Rehnquist rejects this as a possible textual basis for an economic motive requirement by citing a dictionary definition of "affect" for the conclusion that an enterprise could affect commerce without being profit-seeking. $114 \mathrm{~S}$. Ct. at 804 (citing WEBSTER's THIRD NEW INTERNATIONAL DICTIONARY 35 (1969)). The second possibility rejected 


\section{CONCLUSION}

\section{A. Meaning Cannot Be Found in "The" Dictionary}

As we received comments on prior drafts of this essay, we were struck by how often law-trained reviewers asked some version of the following question: "So how is this analysis really any better than just looking in the dictionary?" A superficial answer would be to point to the variance in the definition of enterprise among leading dictionaries discussed above in connection with the NOW case. Moreover, there is no single reference book which is The Dictionary, but rather a number of competing publications which themselves may differ significantly from edition to edition. Law currently has no rule for identifying only one publisher's edition as The Dictionary, nor is there likely to be a principled basis for such a rule. ${ }^{198}$ But the value of linguistics goes well beyond the fact that it could address the problem of inconsistency among dictionaries as to a particular word definition. Linguistics is not properly seen as a means of supplementing the information provided by dictionaries about word meaning. In fact, linguists do not view dictionaries of their own language as significant primary sources and are unlikely to consult them for guidance in doing their research on word meaning.

We would offer the following additional points as reasons why empirical research is likely to be more informative and reliable than simple recourse to a dictionary:

(1) Dictionaries do not represent facts of a language that are independent of the users of that language. Dictionaries do not legislate usage; if a particular actual usage does not conform with a dictionary's description, it does not follow that the usage is therefore incorrect. ${ }^{199}$

by the Court is the language in $\$ 1962$ (a) and (b), discussed in the Ivic case. 18 U.S.C. $\$ 1962$ (a) (1988) (prohibiting investment of racketeering income in an enterprise); Id. $\S 1962$ (b) (prohibiting acquisition of interest in or control of an enterprise through racketeering activity); see supra notes $149-51$ and accompanying text. Rehnquist concludes that the role of the enterprise entity: in $\$ 1962$ (a) and (b)-as victim of racketeering activity-is significantly different than its role in $\$ 1962$ (c)-as instrument or perpetrator of racketeering. Id. at 804 . The opinion ends by summarily dismissing appeals to legislative history and the rule of lenity with statements that "we believe" and "we think" that the statutory language is unambiguous. Id. at 805-06.

Contrary to our assertion in the sentence preceding this note in the text, the Court's opinion conveys the general impression that NOW was in fact not a hard case at all. All nine Justices thus appear to fall within the group of speakers, represented by the majority of both student and district judge survey respondents, who consider entities with a clear goal to be enterprises, regardless of economic motive, and believe that others share that understanding.

198. The situation would be different, though still problematic, if a convention existed that all lawmakers-legislators, regulation promulgators, and judges alike-would routinely and exclusively refer only to a specified dictionary edition, so that for example the Court in deciding the NOW case could assume with confidence that the 1970 judiciary committees of both Houses had consulted the second edition of Webster's New Twentieth Century Dictionary before deciding to use enterprise as a key term in drafting RICO.

199. The authors expect that readers of this essay have shared their experience of looking up a word in a dictionary to find that none of the definitions match the particular use they have in mind. That 
(2) The fact that a meaning is listed in a dictionary is just evidence that the dictionary makers (lexicographers) observed the word being used in a way consistent with it having that meaning intended. ${ }^{200}$ Nothing can validly be inferred from the fact that a particular meaning is not recorded for a particular word. Dictionary-making is an inexact art, and it often happens that usages are common for some time before lexicographers happen to collect enough of them and realize that they represent a distinct usage, and decide to revise an entry to include that usage. ${ }^{201}$ In contrast, empirical means for enlarging one's database such as the NEXIS search or surveys used for analyzing enterprise are far more reliable means of observing and testing contemporary usage. ${ }^{202}$

(3) Even when a dictionary does record a usage that corresponds to what appears to be a legally relevant meaning, it is dangerous to rely on the way that usage is characterized, categorized, and ordered. Dictionary entries are severely limited by time and space constraints; lexicographers must prepare thousands of dictionary entries, each one of which must fit into a very small space and predetermined format. Whether a particular usage is listed first or last in an entry has no bearing on whether it is the "plainest" meaning for the word in the context in question. ${ }^{203}$ Thus even if a dictionary accurately records and distinguishes among relevant usages, analysis by a linguist would provide much needed guidance for choosing among the different dictionary entries by discovering the use conditions pertinent to each entry. ${ }^{204}$

(4) Dictionaries must provide definitions that are appropriate to thousands of contexts; a linguist can conduct a study in a case-specific context, thereby drawing upon whatever aspects of the context that are likely to be pertinent to readers of that language in that context.

Of course, the different kinds of language issues that arise in hard cases often require other kinds of linguistic expertise than that needed for interpretation of individual word meaning; such cases thus lie entirely beyond

experience does not mean, though, that the particular use is inappropriate. Green found that in 17 randomly selected passages of English narrative prose, an average of $14 \%$ of the uses of nouns, verbs, and adjectives were not listed in a selection of desktop dictionaries. For an earlier survey of narrative prose, see GREEN, PRAGMatics, supra note 6, at 56 n.17.

200. See generally Sidney I. LANDAU, DictionaRIES: THE ART AND CRAFT OF LEXICOGRAPHY (1984).

201. Not only are dictionaries unreliable as evidence of new but accepted usage, but they are also likely to preserve usages that have become archaic without necessarily so indicating.

202. For example, none of the dictionaries we reviewed clearly listed a definition that would cover noneconomic enterprise entities (as distinct from noneconomic enterprise activities) even though both the NEXIS and survey data show clearly that such usages of enterprise are acceptable in contemporary American English.

203. The principles of arranging the glosses ("definitions") varies from dictionary to dictionary; sometimes it is historical or chronological order. It might be by inferred frequency, or it might be by some logical schema. Generally the front matter of the dictionary will explain how entries are structured.

204. For example, the use of enterprise that Webster's Third International Dictionary defines as "readiness to attempt" can be readily distinguished by a linguist from enterprise as "venture, undertaking" by the fact that the former appears in actual use as a mass noun while the latter is used a count noun. See supra text accompanying note 163 . 
the competence of either dictionaries or dictionary makers. Within the scope of this essay alone, we have seen that hard cases can arise from the ways words interact with each other in a particular context, such as the opaque context problem discussed in the Staples case, or from the relation of an utterance to the context of its uttering, such as the nonexistent referent of the original sentence in the Granderson case. In such cases that go well beyond individual word meaning, the specific interpretive problems can be carefully matched to individual subfields of linguistics in ways that are simply unavailable to users of dictionaries. Linguists with expertise in those areas could then provide focused and informed analyses of the language issues in question. ${ }^{205}$

\section{B. Navigating Uncertainty}

It will probably be difficult to dislodge the grip the lawyer or judge has upon the dictionary of his or her choice, both because legal discourse requires constant invocation of authority and because a number of procedural problems arise once the fiction is dissolved that meaning can be "judicially noticed" by pulling a dictionary off the shelf. The very flexibility of language that Solan rightly celebrates is possible precisely because the range of meaning of a word or sentence cannot be limited in advance by prescription but rather is realized in the creativity of actual use. Interpretation of actual usage is thus very complex but also achievable. Perhaps the greatest virtue of Justice Scalia's reformulation of the plain meaning rule is the implicit recognition that "plain meaning" does not necessarily mean "simple" or "determinate" meaning. Indeterminacy does not equate with vacuity of meaning; indeed, as the analyses in this essay show, meaning is frequently indeterminate because a word or phrase can mean so many different things. The challenge in such circumstances is not to attempt to create new meaning in a vacuum but to select among objectively identifiable options in a principled way that produces a coherent discourse.

In a felicitous metaphor, James Boyd White offers this advice to those unsettled by the indeterminacy of legal language: When what seemed to be solid ground becomes water under your feet shifting with every breeze, don't

205. Further, the value of linguistics for the judicial process cannot be judged fully from the three Supreme Court cases analyzed by us and the handful of other cases we discuss from Solan's book, not only because linguistics encompasses a wider range of areas of language study than that upon which we have drawn here, but also because the range of hard cases centering on language issues is of course vastly underrepresented by the cases discussed in this essay. For a report on how a fuller array of linguistic subfields has been applied at the trial level through expert testimony, see Judith $\mathrm{N}$. Levi, Language as Evidence: The Linguist as Expert Witness in North American Courts, ForENSIC LINGUISTICs (forthcoming Spring 1994). 
sink or drift aimlessly: learn to sail! ${ }^{206}$ For those willing to sail, linguistics-like a telescope-may reveal a few more stars by which to steer. 
APPENDIX A. DICTIONARY DEFINITIONS OF ENTERPRISE ${ }^{207}$

The AMERICAN HeRITAGe Illustrated ENCYCLOPEDIC DictionaRY 563 (Houghton Mifflin Co. 1987):

1. An undertaking, especially of some scope, complication, and risk. 2. a. Commercial or economic activity; business: private enterprise. b. A business or company. 3. Industrious effort, especially when directed toward making money. 4 . Readiness to venture; boldness; initiative.

Funk \& Wagnalls New "Standard" Dictionary of the ENGlish LANGUAGE 828 (Funk \& Wagnalls Co. 1959):

1. That which one attempts to perform; any projected task or work upon which one sets out; an undertaking; scheme, especially, a bold or difficult undertaking; 2 . The act of engaging, or the disposition to engage, in difficult undertakings; boldness, energy, and invention exhibited in practical affairs, especially in business.

THE OXFORD ENGLISH DictionarY 293 (2d ed. Clarendon Press 1989):

1. A design of which the execution is attempted; a piece of work taken in hand, an undertaking; chiefly, and now exclusively, a bold, arduous, or momentous undertaking. b. abstr. Engagement in such undertakings. 2. Disposition or readiness to engage in undertakings of difficulty, risk, or danger; daring spirit. 3. .The action of taking in hand; management, superintendence. Obs.

3 THE OXFORD ENCYClopedic ENGLISH DictionaRY 476 (Clarendon Press 1991):

1 an undertaking, esp. a bold or difficult one. 2 (as a personal attribute) readiness to engage in such undertakings. 3 a business firm.

THE RANDOM House DictionaRY OF THE ENGLiSH LANGUAGE 476 (Random House 1966):

1. a project undertaken or to be undertaken, esp. one that is of some importance or that requires boldness or energy. 2. a plan for such a 
project. 3. participation or engagement in such projects. 4. boldness or readiness in undertaking; adventurous spirit; energy. 5. a company organized for commercial purposes; business firm. Syn 1. plan, undertaking, venture.

Webster's NeW TWENTIETH CENTURY Dictionary of the ENGLISH LANGUAGE-UNABRIDGed 606 ( $2 \mathrm{~d}$ ed. The World Publishing Co. 1961):

1. an undertaking; a project.

2. a bold, hard, dangerous, or important undertaking.

3. willingness to venture on such undertakings; readiness to take risks or try something untried; energy and initiative.

4. the carrying on of projects; participation in undertakings.

Syn.-adventure, undertaking, venture.

WEBSTER'S NEW WORLD DictionaRY OF THE AMERICAN LANGUAGE 484 (World Publishing Co. 1968):

1. an undertaking; project; hence, 2. a bold, hard, dangerous, or important undertaking. 3. willingness to venture on such undertakings; readiness to take risks or try something untried; energy and initiative.

4. the carrying on of projects; participation in undertakings.

WEBSTER'S THIRD NEW INTERNATIONAL DICTIONARY OF THE ENGLISH LANGUAGE-UNABRIDGED 757 (Merriam-Webster Inc. 1986):

1 a: a plan or design for a venture or undertaking. b: VENTURE, UNDERTAKING, PROJECT; esp: an undertaking that is difficult, complicated, or has a strong element of risk. c: a unit of economic organization or activity (as a factory, a farm, a mine); esp: a business organization: FIRM, COMPANY. d: any systematic purposeful activity or type of activity. 2: readiness to attempt or engage in what requires daring or energy : a bold energetic questing spirit : independence of thought : INITIATIVE, ENERGY.

THE WORLD BOOK DICTIONARY 705 (World Book, Inc. 1988):

1. an important, difficult, or dangerous plan to be tried; great or bold undertaking. 2. any undertaking; project: a business enterprise. 3 . readiness to start projects; willingness to undertake great or bold projects: 4 . The carrying on of enterprises; a taking part in enterprises. 
APPENDIX B. CITATIONS OF "NON-ECONOMIC" ENTERPRISES

The following is a small but representative sample of the citations from our NEXIS search which denote non-economic enterprises in several categories. The key word enterprise has been italicized for ease of reference.

Academic/scholarly: "Local history enterprises are at their best when they bring together professional historians and local citizens."

Artistic/musical/creative: "The United States has made possible all manner of extraordinary artistic enterprises-for example, the distinctly American triumphs in ballet of George Balanchine and Lincoln Kirstein."

Educational: "It's become very clear that all of the dimensions of our lives are very intimately linked to the improvement of our educational enterprise."

Government: "The party advocates making government enterprises and schools private, cutting taxes, ending rent control ... and phasing out Social Security."

Journalistic: "Mr. Vecchione said of the [NBC series featuring Dr. Koop]: 'I don't consider it a journalistic enterprise. I consider it consider it in the realm of information programming and public affairs."”

Scientific/research: "This allegation of fraud is both without basis and irrelevant to Dr. Baltimore's qualifications for leading a world-class scientific enterprise." 


\section{APPENDIX C. SURVEY ITEMS}

Survey A asked whether the following six examples were enterprises:

A weekly Bible study group directed by a Lutheran minister conducts discussion of various New Testament verses. The group's only activity is the Bible discussions.

The Coalition for Fair Adoption Laws (CFAL) is a highly organized national network of non-profit organizations representing adoptive parents and persons seeking to adopt. The executive directors of the member organizations comprise the steering committee of CFAL. CFAL's activities include lobbying, rallies, and planning demonstrations at courts and adoption agencies.

Fifty Civil War enthusiasts meet once a year to re-enact part of the Battle of Gettysburg. Each person covers his own expenses and contributes $\$ 100$ towards the costs of the re-enactment; there is a loose steering committee of five who do the pre-event organizing.

The Independent Quebec Organization is a terrorist group that robs banks and extorts money from wealthy, French-speaking Canadians to finance its bombing, arson, and assassination activities.

A small company (10 stockholders, 30 employees) manufactures and sells vending machines.

The Internal Revenue Service.

Survey B asked about the following six examples:

Five people, who had never met before, play poker one night at a casino table in Las Vegas.

The Movement for Fair Adoption Laws (MFAL) is an unstructured network of political activists, who favor freer adoption. With much intercommunication among "members," MFAL's activities consist of, among other things, planning demonstrations at courts and adoption agencies.

Eleven middle-aged men play touch football games every weekend against seven other such teams. The team members do not know each other outside the context of the team. The teams contribute $\$ 500$ each toward a $\$ 4000$ pot to be won by the champion team at the end of the summer.

The IBM (International Business Machines) Corporation.

Three children selling lemonade on a street-corner. 
The United Auto Workers.

Survey C contained four items from Survey A: the weekly bible study group, the Coalition for Fair Adoption Laws, the Independent Quebec Organization, and the Internal Revenue Service. It also contained two items identical to those of Survey B: the three children selling lemonade and the United Auto Workers. 


\section{APPENDIX D. EXAMPLES OF THE "WHY/WHY NOT" RESPONSES}

The following data illustrate the strength of the relationship between the two ways of identifying an enterprise, the "having a goal" and the "seeking a profit" approaches, and the scores given for a particular question. The information below combines the answers from San Diego State University students and Washington University students to the "Why/Why Not" question in regard to whether the Coalition for Fair Adoption Laws (CFAL) is an enterprise. The first column contains the subject numbers (with an asterisk denoting Washington University subjects), the second column indicates the scores of the subjects' answers, and the third column contains the subjects' "Why/Why Not" responses.

\begin{tabular}{|c|c|c|}
\hline A3 & 7 & This group is specifically organized to do something. \\
\hline A9 & 7 & Undertaking a specific goal \\
\hline *A2 & 7 & $\begin{array}{l}\text { Because it is an organization that raises } \$ \text { and seeks } \\
\text { members to carry out its intentions }\end{array}$ \\
\hline *A4 & 7 & It has leadership and a goal \\
\hline $\mathrm{A} 1$ & 6 & $\begin{array}{l}\text { They're gathering in order to achieve something in } \\
\text { society. }\end{array}$ \\
\hline A2 & 6 & $\begin{array}{l}\text { Clear goals with measurable outcome re laws, } \\
\text { procedures, successes. }\end{array}$ \\
\hline A5 & 6 & [no response] \\
\hline A10 & 6 & Tight focus or purpose; goal \\
\hline \#5 & 6 & Maybe not bec. is non-profit groups \\
\hline *A6 & 6 & Speading idea enterprise of "selling" idea \\
\hline$\because A 9$ & 6 & [no response] \\
\hline A7 & 5 & They are organized in an effort to do something \\
\hline$\because \mathrm{A} 1$ & 5 & They are all working together \\
\hline$\because A 10$ & 5 & Have an established goal \\
\hline $\mathrm{A} 4$ & 4 & $\begin{array}{l}\text { In one sense yes because it is a sort of business, but no } \\
\text { because I also have an idea that it should make money. }\end{array}$ \\
\hline A11 & 4 & [no answer] \\
\hline A13 & 4 & [no answer] \\
\hline$\because \mathrm{A} 3$ & 4 & I have no clue \\
\hline A6 & 2 & This group is non-profit \\
\hline A12 & 2 & I'm sticking with business \\
\hline *A7 & 2 & [no response] \\
\hline$\because A 8$ & 2 & Non-profit \\
\hline A8 & 1 & This would imply commercial undertones \\
\hline
\end{tabular}

Overall average: 4.7 


\section{APPENDIX E. GENERALIZATIONS FROM THE "WHY/WHY NOT" RESPONSES}

All 23 respondents to Survey A, and 28 of the 33 respondents to Survey B, responded meaningfully to at least some of the "Why/Why Not" questions. (Irrelevant responses such as "Maybe" were excluded.) The properties of the potential "enterprises" that subjects mentioned in their responses are listed in Table A.

\section{TABLE A.}

Property

Profit orientation

Goal orientation

Having group unity; cohesion

Being formal, serious, or "official"

Having structure

Having a certain size

Unlawfulness or "Negativity"

Being private vs. governmental
Number of subjects Total number of who mentioned the times mentioned property

$\begin{array}{rr}33(64.7 \%) & 111 \\ 28(53.9 \%) & 72 \\ 13(25.5 \%) & 40 \\ 11(21.6 \%) & 6 \\ 8(15.7 \%) & 11 \\ 8(15.7 \%) & 5 \\ 7(13.7 \%) & 6 \\ 6(11.8 \%) & 8\end{array}$

In Table A, the percentages add up to more than $100 \%$ because some subjects mentioned more than one property. The group of 28 subjects who mentioned goal orientation does not include subjects who mentioned profit orientation without identifying this as a goal, even though profit-seeking is a kind of goal.

The "Why/Why Not" data can also be used to classify subjects with respect to the two leading criteria, profit orientation and goal orientation. Table B gives the numbers of respondents to Surveys A and B who mentioned either, both, or neither of these criteria.

TABLE B.

\section{Criteria}

Profit, but not Goal Goal, but not Profit Goal and Profit Neither Goal nor Profit
Number of subjects mentioning those criteria

21 (10 Survey A, 11 Survey B)

16 (6 Survey A, 10 Survey B)

12 (6 Survey A, 6 Survey B)

2 (0 Survey A, 2 Survey B)

Table B shows that of the 23 Survey A respondents who provided "Why/Why Not" rationales, 12 mentioned goal orientation in their rationale for at least one of their judgments, and 16 mentioned profit orientation. It also shows that of the 29 Survey B respondents who provided "Why/Why Not" rationales, 16 mentioned goal orientation and 17 mentioned profit orientation. Among all 
respondents who provided "Why/Why Not" rationales, $31 \%$ mentioned "goal" alone, $41 \%$ mentioned "profit" alone, $41 \%$ mentioned both "goal" and "profit," and $4 \%$ mentioned neither. 


$$
\text { - }
$$

